\title{
ECONOMICS
}

\section{Automation and Inequality with Taxes and Transfers}

\author{
Rod TYERS \\ Business School \\ University of Western Australia, \\ Research School of Economics, \\ Centre for Applied Macroeconomic Analysis (CAMA) \\ Australian National University
}

Yixiao ZHOU

School of Economics and Finance

Curtin Business School

Curtin University 


\title{
Automation and Inequality with Taxes and Transfers**
}

\author{
Rod TYERS \\ Business School \\ University of Western Australia, \\ Research School of Economics, \\ Centre for Applied Macroeconomic Analysis (CAMA) \\ Australian National University \\ Yixiao ZHOU \\ School of Economics and Finance \\ Curtin Business School \\ Curtin University
}

Revised November 2017

Key words:

Automation, income distribution, tax, transfers, general equilibrium analysis

JEL Codes:

C68, D33, D58, O33

Author best contact details:

Rod Tyers

Winthrop Professor of Economics

UWA Business School

Crawley, WA 6009

Australia

rod.tyers@uwa.edu.au

\footnotetext{
** Thanks for assistance with the literature review are due to Alex Dixon and Grace Taylor. For useful comments and discussions we also thank Markus Brueckner, Peter Dixon, Bob Gregory, Warwick McKibbin, Ivan Roberts, John Simon and Xiaobo Zhang, along with participants in seminars at the UWA Business School and the Melbourne Centre for Policy Studies. The model used in the paper is solved using the Gempack software.
} 


\title{
Automation and Inequality with Taxes and Transfers
}

\begin{abstract}
The dependence of real income and inequality on changes in factor abundance, total factor productivity, factor bias, the relative cost of capital goods and the progressivity of the tax system are quantified using an elemental general equilibrium model with three households. Observed declines in low-skill labour shares are shown to have been generic in the OECD and to have been responsible for most of the increase in US inequality between 1990 and 2016. The widely anticipated future twist away from low-skill labour toward capital is then examined, in combination with expected changes in population and its skill composition. With downward rigidity of low-skill wages the potential is identified for unemployment to rise to extraordinarily high levels. Productivity growth at twice the pace since 1990 is shown to limit this, though it does not slow the concentration of income. The superior policy response is shown to be a generalization of the US "earned income tax credit" system, with financing from taxes on consumption, rather than capital income.
\end{abstract}

\section{Introduction}

Three prominent trends in global economic performance have arisen in the past three decades. First, rates of growth in economic activity in advanced economies have declined, most notably during the first decade of the millennium (Lo and Rogoff 2015). Second, when this is combined with the declining trend in global bond yields at all maturities, it suggests a revival of "secular stagnation" (Summers 2014, 2016). And third, most prominently in the advanced Anglo economies, there has been a trend toward the capture of what new income and wealth is generated entirely by high level professional and capital-owning households (Piketty 2014). It comes as no surprise that these three issues are related (Pichelmann 2015) and that they depend, at least in part, on technical changes in the period (Gordon 2014, 2015). In the early 2000s levels of real net investment in the advanced economies began to decline. Other things equal, these slower rates of capital accumulation would have slowed the uptake of embodied technology and the growth of total factor productivity (TFP). Indeed, TFP stagnated quite suddenly across the OECD around this time and there has since been little sign of resurgent growth. At the same time the steady decline in the share of the low-skilled in value added throughout the OECD and transitional economies has been widely noted (OECD 2012, Autor et al. 2017b). ${ }^{1}$ Explanations posited for this include East Asian

\footnotetext{
${ }^{1}$ The complementary rise in the capital share of income is the prime focus of Piketty (2014), Piketty and Zucman (2014) and Rognlie (2015). Beyond the OECD, trends in factor shares have been in the spotlight more broadly (Zhou 2016). Applications to China include those by Fleisher et al. (2010), Zhou and Song (2016), Kanbur et al. (2017) and Zhou and Tyers (2017).
} 
comparative growth and trade, ${ }^{2}$ the rise of the property rights component of intangible capital (Kho et al. 2016), the interaction between IT development and the diminution of competition within IT-intensive oligopolies with low labour intensity (Ezrachi and Stucke 2016, Moazed and Johnson 2016, Autor et al. 2017a) and the wider displacement of workers by increasingly intelligent machines (Acemoglu and Autor 2011, Acemoglu and Restrepo 2015, Susskind and Susskind 2015, and Autor 2016).

In this expanding literature it is possible, loosely, to separate the views of "techno pessimists and optimists”. Some pessimism emerges from Gordon (2014, 2015), who sees the major gains in capital-embodied productivity in the past and, in effect, recognizes what has become known as the "Solow paradox" 3 , the obvious spread of information technology (IT) in the face of its apparent lack of evidence in productivity statistics. Beyond this, the continuing IT revolution has a widely recognized dark side, which sees the potential for automation to outpace human capital adjustment to such an extent that it threatens the role of employment in distributing income. ${ }^{4}$ Particularly ardent pessimists see artificial intelligence (AI) as necessitating an inevitable "singularity” by which human influence over technology will cease (Kurzweil 2005, Barrat 2013, Nordhaus 2015) and machines that are so adaptable that they will drive almost all workers out of the production process (Susskind 2017). Moreover, the ownership and frontier implementation of new technologies, software and know-how is increasingly concentrated across regions (Khanna 2016). As Ford $(2015,2016)$ suggests, the issue is not that we may no longer have "broad-based" innovation; it is that modern innovation may no longer procure broad-based prosperity. ${ }^{5}$ By contrast, the techno-optimists see immense potential for productivity and lifestyle improvements from the further expansion of modern IT, AI and robotics. Mokyr (2013) and Mokyr et al. (2015) argue that, technology anxiety notwithstanding, we are on the cusp of a new era of progress in innovation that will provide an unprecedented boost to productivity.

\footnotetext{
${ }^{2}$ The roles of China, and Asian trade more generally, in US labour market performance in the 2000s are explored by, among others, Pierce and Schott (2012), Autor et al. (2013), Arora et al. (2015), Acemoglu et al. (2016) and Tyers (2015, 2016).

${ }^{3}$ Acemoglu et al. (2016) note Robert Solow's comment in his 1987 New York Times Book Review article: “... what everyone feels to have been a technological revolution, a drastic change in our productive lives, has been accompanied everywhere, including Japan, by a slowing-down of productivity growth, not by a step up. You can see the computer age everywhere but in the productivity statistics.”

${ }^{4}$ Key contributors include Brynjolfsson and Andrew (2011), OECD (2012), Goos et al. (2014), Hemous and Olsen (2014) and Avent (2016).

${ }^{5}$ Households dependent for their incomes on work, once referred to as the "proletariat", are now being referred to as the "precariat", facing higher employment risk and stagnant prospects (Das 2016 a \& b).
} 
In this paper we do not address the debates over the relative contributions of the proposed explanations for observed changes in factor shares through time. Instead, we focus on the associations between these and other economic changes and the inequality of disposable incomes. The evidence on total factor productivity and factor bias in key OECD countries since 1990 is first briefly explored. Then the economy-wide effects of it are investigated directly via an elemental general equilibrium model with multiple households. This is used in a decomposition of observed changes since 1990, for the US, and an analysis of prospective shocks that are expected to affect future economic performance and inequality. The real disposable incomes and the inequality between three represented households are examined in response to changes in factor abundance, total factor productivity, factor bias, the relative cost of capital goods, labour force participation rates and the progressivity of the tax system. Changes in factor bias that advantage skill and capital, relative to low-skill labour, emerge as the dominant explanators of the rise in inequality in that period.

The model is then applied to a set of shocks that constitute a "central projection" over a further two decades, around which the effects of further changes in factor bias, population growth and its composition, and TFP are explored in a sensitivity analysis. Unemployment at unprecedented rates emerges as a possibility, made worse by the anticipated population increment if its skill content remains low. In this context a system of transfers to low-skill households is compared with flexible wages and "earned income tax credits", with either system financed alternatively from taxes on capital income and consumption. The earned income tax credit system emerges as superior, in combination with increased taxation of consumption expenditure. In the end, however, much depends on the rate of TFP growth. If it is weak and the "Solow paradox" persists, there will be no politically feasible escape from increased transfers. If it is strong, inequality will continue to increase but the prospect of rising unemployment or declining real consumption wages can be avoided.

Section 2 reviews data on technical change and income distribution in key advanced economies while Section 3 describes the general equilibrium framework used to conduct the analysis. Section 4 offers the decomposition analysis for the case of the US over 1990-2016 and Section 5 addresses prospective shocks and their distributional consequences. Section 6 then concludes. 


\section{Technology, Factor Shares and Inequality in Advanced Economies}

That inequality has risen across the OECD countries since the 1960s is clear from Figure 1. To examine how much this rising trend in income inequality is driven by technical change we first investigate changes in measured TFP and factor payment shares. Two striking trends emerge: a slowdown in TFP growth and a twist in shares away from low-skill labour. We then examine the dispersion of wage incomes in the US in search of complementary patterns.

\subsection{Technology indicators}

The slowdown in TFP growth is clear from Figure 2, which shows the turning point following which TFP stagnated to have been during the early 2000s, prior to the GFC. This is true on average for the OECD and, as shown in Figure 2, for key individual economies, including the US, Great Britain (the UK) and Australia. The UK had taken the lead in TFP growth early on, in part because of its specialization as a delivery centre for services of low capital intensity to the European Union (EU). The US caught up via the agency of its IT boom in the 1990s. Australia's shift to efficient service delivery and IT uptake in that period saw its productivity also surge. These three regions out-performed the OECD as a whole, though all began to stagnate before the GFC.

Changes after 1995 in the shares of expenditure by producers on capital, low-skill labour and skill are examined in Figure 3 for the US, the UK, Australia and the OECD as a whole. The low-skill labour share is that of payments to "medium- and low-skilled" persons in value added, while the skill share is that of payments to high-skilled persons in value-added. For the OECD as a whole and for all the individual regions listed, the low-skill labour share declined significantly, from 42 per cent to 35 per cent across the OECD. By contrast, there was a surge in the skill share over this period, from 20 per cent to 25 per cent across the OECD. Capital shares rose more modestly, from 38 per cent to 40 per cent across OECD, so the major beneficiaries of the incremental factor bias were professional workers.

\subsection{Dispersion in real wage incomes}

The modern literature exploring the determinants of wage dispersion in advanced economies expanded during the late 1980s following deterioration in the labour market performance of low-skill US and European workers. An extensive survey, grounded in the StolperSamuelson Theorem, was offered early on by Wood (1994). The early empirical studies focussed on the links between trade and US labour market performance (Bound and Johnson 
1992, Borjas and Ramey 1994, Berman et al. 1994 and Leamer 1996). These studies were driven by the observed rise in the skill premium from the late 1980s, seen in the early 1990s in Figure 4. Each contributor sought to apportion blame for the dispersion between trade with developing countries (particularly “outsourcing”) on the one hand and labour-saving technical change on the other, with all attributing at least part of the effect to trade. Complementary global general equilibrium studies emerged at the time, beginning with Krugman (1995) and proceeding to the decomposition studies by Tyers and Yang (1997, 2000) and Francois and Nelson (1998), both of which suggested that strong growth in developing trading partners had been welfare improving in the developed economies and that technical change was more important than trade in determining labour market performance. ${ }^{6}$

As can be seen from Figure 4, later in the 1990s the heat came out of this debate temporarily when the US ICT boom stabilised the level of dispersion and lifted all real wage incomes. It was again resurgent after China’s accession to the WTO in 2001. Its growth then accelerated and it became the dominant developing trading partner and the dominant global manufacturer. The resurgent literature noted that the performance of all US worker occupation groups (bar the top one per cent) deteriorated after 2000 (Haskell et al. 2012, Pierce and Schott 2012). This is consistent with the final trends in Figure 4, which show a further widening in the dispersion of real wage incomes and deteriorating real incomes to low-skill workers. These trends appear consistent with the aggregate changes in the levels of US population, employment and human capital stock to emerge from the Penn World Tables (Feenstra et al. 2015) and illustrated in Figure 5. Relative to the path of population growth, these show a slowing in the rate of human capital accumulation after 1990 and in total employment after 2000. Further theories that depend on new models have emerged to address these changes and the implied underlying choices of technique. These combine innovative technical changes with greater roles for trade and competition behaviour than had been considered in the earlier literature. ${ }^{7}$

\subsection{The suffering "middle”}

The comparatively poor labour market performance of workers in the middle skill levels was noted early on by Gregory (1993) for the US and Australia, and more recently by Acemoglu

\footnotetext{
${ }^{6}$ Somewhat later a similar conclusion is drawn from dynamic global modeling by McKibbin and Woo (2003). ${ }^{7}$ See, for such explanations, Helpmann et al 2010, Autor et al. 2013, Ezrachi and Stucke 2016, Moazed and Johnson 2016, and Autor et al. 2017. Earlier work had also shown that product differentiation could limit the penetration of external terms of trade shocks to domestic labour markets (Tokarick 2005) and wage distribution effects were shown to depend on capital-skill complementarity (Tyers and Yang 2000, Winchester and Greenaway 2007).
} 
and Autor (2011) and Autor (2016). In our above analysis of factor shares, and in our modelling below, the middle group is combined with the very low-skill group to form the "low-skill” group. Nonetheless, the implications of technical change for this group appear to have been significant and this is worth mention. Table 1 presents the changes in skill earnings gaps in OECD economies from the year 2002 to the year 2014. Overall, the gap between high- and medium-skill earnings widened and that between medium- and low-skill earnings narrowed, which suggests the twist was in the dispersion of earnings between highskill persons and the combined medium- and low-skill group. This is consistent with Autor's assertion that it is workers of medium skill that have been most vulnerable to automation and outsourcing and that of Beaudry et al. (2017) that the penetration of automation into the advanced professional sector is causing highly trained professionals to compete in the middle skill range.

\section{Modelling the Economy-Wide Consequences of Automation}

A single product, real general equilibrium structure is used that has a complete financial market with government debt and three household groups. On the supply side, there are three primary factors with "production" labour $(L)$ a partially unemployed variable factor. In standard closures the stocks of physical capital $(K)$ and skill $(S)$ are exogenous and fully employed. The three households have differing shares of the three primary factors and different consumption behaviour, dependent on current and expected future disposable income and a common interest rate, which clears the financial market.

\subsection{The supply side}

Since technology is exogenous and subject to shocks in this analysis, a "relative CobbDouglas” formulation allows us to capture changes in productivity and factor bias separably, via simple changes in readily observed parameters: a total factor productivity parameter, $\theta$, and a set of factor shares, $\beta$.

$$
\frac{y}{y_{0}}=\theta\left(\frac{L}{L_{0}}\right)^{\beta^{L}}\left(\frac{S^{K}}{S_{0}^{K}}\right)^{\beta^{S}}\left(\frac{K}{K_{0}}\right)^{1-\beta^{L}-\beta^{S}},
$$

where $y_{0}, L_{0}, S_{0}^{K}$, and $K_{0}$ are the initial levels of output and labour, skill and capital inputs. This formulation allows technology bias shocks, to $\beta^{L}$ and $\beta^{S}$, to be neutral so far as the initial 
level of aggregate output is concerned. ${ }^{8}$ Marginal products are then:

$$
M P^{L}=\beta^{L} \frac{y}{L}, \quad M P^{S}=\beta^{S} \frac{y}{S^{K}}, \quad M P^{K}=\left(1-\beta^{L}-\beta^{S}\right) \frac{y}{K}
$$

The real production wages of unskilled and skilled workers depend conventionally on the corresponding marginal products:

$$
w=\frac{W}{P^{P}}=\beta^{L} \frac{y}{L}, \quad w^{S}=\frac{W^{S}}{P^{P}}=\beta^{S} \frac{y}{S^{K}} .
$$

Here the upper case wages are nominal (expressed relative to the numeraire, the GDP price) and the lower case wages are real (expressed relative to the producer price, $P^{P}$ ).

\section{Output, GDP and prices:}

The real volume of output, $y$, is distinguished from nominal GDP, $Y=P^{Y} y$, where $P^{Y}$ is the GDP price level (deflator). ${ }^{9}$ Direct and indirect tax revenues, $T^{D}$ and $T^{I}$, and transfers to households, $T^{R}$, play key roles in the formulation. GDP at factor cost (or producer prices), $Y^{F C}$, is the total of direct payments to the collective household in return for the use of its factors. Nominal GDP is then

$$
Y=Y^{F C}+T^{I}, \quad Y^{F C}=C+\left[T^{D}-T^{R}-\alpha W_{0}(F-L)\right]+S^{P} .
$$

This is the standard disposal identity for GDP, or the collective household budget, where $C$ is the total value of final consumption expenditure, including indirect taxes paid, $S^{P}$ is private saving and the term in square parentheses is direct taxation net of transfers to households (the latter including non-specific transfers, $T^{R}$, and unemployment benefits at fraction, $\alpha$, of the initial low-skill wage). $L$ is low-skill employment and $F$ is the low-skill labour force. In this context the GDP price, $P^{Y}$, and the producer price, $P^{P}$, would be the same were it not for indirect taxes. In their presence we have:

$$
Y=P^{Y} y=P^{P} y+T^{I} \text {, so that } P^{Y}=P^{P}+\frac{T^{I}}{y} .
$$

\footnotetext{
${ }^{8}$ In effect, shocks to factor shares alone adjust the initial level of total factor productivity, so that the question becomes, how different would the economy have been had the factor shares been at their post-shock levels. Such shocks do not necessarily hold output constant, however, since this depends on whether real wage rigidities cause changes in unemployment.

${ }^{9}$ In this real model, "nominal” refers to prices relative to the model numeraire, which is arbitrary but is chosen to be the GDP price $P^{Y}$. The producer price, $P^{P}$ and the consumer price level, $P^{C}$, vary relative to this value in response to shocks.
} 


\section{Population and participation:}

The three separate households, $h$, are defined based on factor ownership. The first has income dominated by production labour, the second by skill and the third by capital. Because few households depend on only one factor of production, the three are defined based on the stylised factor ownership shares, $s_{h f}$, offered in Table 2. The low-skill and skilled labour forces depend not only on these ownership shares but also on separate participation rates. All three households supply low-skill workers and skill but at different participation rates, $\lambda_{L h}$ and $\lambda_{S h}$ (defined here as the ratios of participating, full time equivalent, worker-years to populations). The links between the low-skill and skilled labour forces and the three household populations are then:

$$
N_{h}=\frac{s_{h L} L}{\lambda_{L h}}+\frac{s_{h S} S^{K}}{\lambda_{S h}}
$$

This level of detail in labour supply is required not only for labour market equilibrium but also for the eventual construction of Lorenz curves. Apart from their significance for labour supply and real wages, changes in unemployment and participation rates influence welfare via dependency ratios within each household group.

\subsection{The demand side}

Central to the demand side in any economy-wide model is the financial market, which equates saving to investment. Here investment depends on the expected after-tax yield, or the rate of return on installed capital net of depreciation and capital tax, adjusted for sovereign risk, $r^{c e}$. This has a number of components. First, since only the after-depreciation component of capital income is taxed, after tax capital income is:

$$
Y_{K N}=\left(1-t^{K}\right) K\left(P^{P} M P_{K}-P^{K} \delta\right),
$$

where $P^{K}$ is the price of capital goods, ${ }^{10} t^{K}$ is the ad valorem capital income tax rate and $\delta$ is the depreciation rate. The rate of return net of both tax and depreciation is then:

$$
r^{c}=\frac{\left[P^{P} M P_{K}-t^{K}\left(P^{P} M P_{K}-P^{K} \delta\right)\right]}{P^{K}}-\delta .
$$

\footnotetext{
${ }^{10}$ In this single product model the product and capital goods prices are separated by a single parameter: $P^{K}=\gamma P^{P}$. This allows shocks to represent the relative cheapening of capital goods over time as their information technology content rises.
} 
The expected form of this rate is then:

(9) $\quad r^{c e}=r^{c}\left(\frac{\varphi^{0}}{\varphi}\right)$,

where the interest premium factor, $\varphi$, permits consideration of the effects of changes in the fiscal balance on sovereign risk. A deteriorating fiscal balance causes investment to be less attractive.

$$
\varphi=\varphi^{0}\left[\left(\frac{G}{T} / \frac{G_{0}}{T_{0}}\right)\right]^{\phi},
$$

where $\phi$ is a positive elasticity indicating sensitivity to sovereign risk.

The demand for investment financing depends on the “Tobin's Q like” ratio of the expected rate of return on installed capital, $r^{c e}$ and a domestic market clearing bond yield or financing rate, $r$, which differ so long as the economy is not in a financial steady state.

(11) $\frac{I^{D}}{I^{0}}=\left(\frac{r^{c e}}{r}\right)^{\varepsilon^{I}}$,

where $\varepsilon^{I}$ is a positive elasticity. This investment demand is then matched by a supply of saving that incorporates the government's fiscal position:

$$
I^{D}=S^{D}=S^{P}+\left(T^{D}+T^{I}-G\right)
$$

where $T^{D}$ and $T^{I}$ are, respectively, direct and indirect tax revenues, $S^{P}$ is private saving and $G$ is the total of all the government's expenditures, including those on goods and services, $G^{X}$, transfers to households, $T^{R}$, and unemployment benefits, which are paid at a fraction, $\alpha$, of the initial nominal low-skill wage, $W_{0}$ :

$$
G=G^{X}+T^{R}+\alpha W_{0}(F-L), \quad T^{R}=\sum_{h} T_{h}^{R}, \quad T_{h}^{R}=t_{h}^{R} Y N_{h},
$$

where $F$ is defined in (5) as the total low-skill labour force, $t_{h}^{R}$ is the proportion of GDP that is paid out to household $h$, per capita (the fundamental constant underlying transfers), and $N_{h}$ is the household's population.

Calibration of the financial market is facilitated by the assumption that the initial database has the steady state property that the net rate of return is initially the same as the market bond 
yield: $r_{0}^{c e}=r$. Thus, the financial market clearing condition endogenizes $r$ by equating the value of domestic investment, $I^{D}$, which represents the sum total of all domestic long maturity asset issues, with demand for those assets in the form of net (private and government) savings.

\section{Direct tax}

Constant marginal direct tax rates, $t^{W}, t^{S}$ and $t^{K}$, apply to all labour, skill and capital income, respectively. The corresponding "powers" of these rates are $\tau^{L}=\left(1+t^{L}\right), \tau^{S}=\left(1+t^{S}\right)$ and $\tau^{K}=\left(1+t^{K}\right)$ and so, bearing in mind taxation of capital income after depreciation (6), total direct tax revenue is:

$$
T^{D}=t^{L} W L+t^{S} W^{S} S^{K}+t^{K} K\left(P^{P} M P_{K}-P^{K} \delta\right) .
$$

Indirect tax revenue, $T^{I}$, depends on consumption and so it will emerge later.

\section{Household disposable income and consumption}

Disposable income, for each household, takes the form:

$$
\begin{aligned}
Y_{h}^{D}= & s_{h L}\left[\left(1-t^{L}\right) W L+\alpha W_{0}(F-L)\right]+s_{h S}\left(1-t^{S}\right) W^{S} S^{K} \\
& +s_{h K}\left(1-t^{K}\right) K\left(P^{P} M P_{K}-P^{K} \delta\right)+T_{h}^{R}, \quad \forall h
\end{aligned}
$$

where $T_{h}^{R}=t_{h}^{R} N_{h} Y$ is a direct transfer to the household from government revenue, with $t_{h}^{R}$ the transfer rate to household $h$ per unit of group population, $N_{h}$, and per unit of nominal GDP. ${ }^{11}$ Total disposable income is the sum of $Y_{h}^{D}$ across households, which is also GDP at factor cost (household primary income) less total direct taxes, plus net transfers from the government to households and the unemployed: $Y^{D}=\sum_{h} Y_{h}^{D}=Y^{F C}-T^{D}+T^{R}+\alpha W_{0}(F-L)$.

Since, from (5), GDP at factor cost is full GDP less net indirect tax revenue, this can be written as

$$
Y^{D}=Y-T^{I}-T^{D}+T^{R}+\alpha W_{0}(F-L) .
$$

For each household, $h$, aggregate consumption expenditure, $C_{h}$, is a nominal sum but real

\footnotetext{
${ }^{11}$ The expression (15) is more complex if the labour force participation rates, as defined in (6), of low skill workers, $\lambda_{L h}$, are unequal across households and, similarly, if participation rates of skilled workers, $\lambda_{S h}$, are unequal across households. The simpler expression is offered here since this is not the case in this analysis. The participation rates within skill groups and across households are kept equal in the experiments conducted, although the rates differ between skill groups and may be differently shocked.
} 
consumption behaviour is motivated by current and expected future real disposable incomes and the real interest rate. Real consumption, (lower case) $c_{h}$, depends negatively on the aftertax real return on savings (the home bond yield, $r$ ) and positively on both current and expected future real disposable income:

$$
c_{h}=\frac{C_{h}}{P^{C}}=A_{h}^{C}\left(\frac{r}{\tau^{K}}\right)^{-\varepsilon_{h}^{C R}}\left(\frac{Y_{h}^{D}}{P^{C}}\right)^{\varepsilon_{h}^{C Y}}\left(\frac{Y_{h}^{D e}}{P^{C}\left[1+\pi_{h}^{C e}\right]}\right)^{\varepsilon_{h}^{C Y}},
$$

where the expected inflation rate of the consumer price level is $\pi^{c e} \cdot{ }^{12}$ The different households have parameters reflecting different sensitivities to these determinants. The consumer price level is marked-up over the producer price level by the power of the consumption tax, $P^{C}=\tau_{C} P^{P}$. This yields consumption tax revenue:

$$
T^{I}=\left(\tau_{C}-1\right) P^{P} \sum_{h} c_{h}
$$

\section{Private saving}

Households receive factor incomes amounting to GDP at factor cost, $Y^{F C}$. Their disposal of nominal income is this sum less direct tax, net of transfers to households and the unemployed (16). Private saving differs across households. It is what remains after consumption expenditure (gross of indirect taxes) is further deducted from disposable income.

$$
S^{P}=\sum_{h}\left[Y_{h}^{D}-C_{h}\right]
$$

Since total consumption expenditure, inclusive of consumption tax, is

$$
C=\sum_{h} C_{h}=P^{C} \sum_{h} c_{h}=P^{P} \tau_{C} \sum_{h} c_{h},
$$

And total disposable income is from (16), aggregate private saving can also be written as:

$$
S^{P}=Y^{D}-C=\left[Y-T^{I}-T^{D}+T^{R}+\alpha W_{0}(F-L)\right]-C
$$

\section{Government and total domestic saving}

This is government revenue less government expenditure, both measured net of direct transfers to households and the unemployed. Total domestic saving is then the sum of private and government savings in the home economy, in home currency, where government saving is $S^{G}=T^{D}+T^{I}-T^{R}-G^{X}-\alpha W_{0}(F-L)$.

\footnotetext{
${ }^{12}$ There is no money-driven inflation in this model but expectations can be formed of a future increase in the consumption tax rate that would raise $P^{C}$ relative to $P^{P}$ and $P^{Y}$.
} 


$$
S^{D}=S^{P}+S^{G}=Y-C-G^{X}
$$

\section{The product balance}

Product balance stems from a version of the expenditure identity in real volume terms:

$$
y=\frac{I+G^{X}}{P^{P}}+\sum_{h} c_{h},
$$

where the final term is the sum of real consumption across the households. Neither investors nor the government pay indirect taxes on their expenditure and so the price they face for the home product is the producer price, $P^{P}$.

\section{Welfare and inequality}

For distributional analysis, the shares of disposable income and the population shares are then

$$
s_{h}^{Y D}=Y_{h}^{D} / Y^{D}, \quad s_{h}^{N}=N_{h} / \sum_{i=1}^{H} N_{i}, \quad \forall h \in(1, H) .
$$

Our measure of group welfare is real disposable income at consumer prices, $V_{h}=Y_{h}^{D} / P_{C}$ and a three-group Gini coefficient is calculated, first by calculating the area under the threehousehold Lorenz curve:

$$
A_{L}=0.5\left[s_{L h}^{N} s_{L h}^{Y D}+s_{S h}^{N}\left(2 s_{L h}^{Y D}+s_{S h}^{Y D}\right)+s_{K h}^{N}\left(1+s_{L h}^{Y D}+s_{S h}^{Y D}\right)\right],
$$

and the corresponding Gini coefficient is then

$$
G^{C}=2\left(0.5-A_{L}\right) \text {. }
$$

\section{Financial wealth}

The growth path of the US economy has not been in a steady state for three decades, with asset prices inflating relative to product prices by at least six percentage points per year on average. $^{13}$ This implies growth in financial wealth relative to GDP, due superficially to growth in realized rates of return relative to financing rates and, more fundamentally, to the cheapening of capital relative to other goods and a rise in saving supply due to income concentration in comparatively high-saving households. Financial wealth is simply represented as the present value of an infinite stream of dividends equal real returns on the capital stock, $r^{c e}$ from (9), discounted at the current financing rate, $r$. The variable of interest is the ratio of financial wealth to GDP:

\footnotetext{
${ }^{13}$ This is readily concluded from a comparison of the path of a broad index of stock prices, such as the Wilshire Capital Price Index, and the US CPI, since 1990.
} 


$$
W^{F} / y=\left(\frac{r^{c e}}{r}\right)\left(\frac{K}{y}\right)
$$

Parameters, database and operation:

A complete list of the behavioural parameters used in the model is provided in the Appendix, Table A1. The model is structured to resemble the US economy in 2016. The database is built on national accounts as well as financial data for that year. Closures required to undertake the experiments for Sections 4 and 5, below, are detailed in Table A2. The model code and working software are available on request from the authors. Finally, a particularly important element of the database concerns the assets of all three represented households: low income, professional and capital-owning. The ownership shares of each, across low-skill labour, skill and physical capital, are detailed in Table 2. Most notably, the low-income and professional households do have some capital assets, mainly in the form of housing and the capital-owning households do offer some low-skill and high-skill labour.

\section{Simulating US Growth and Inequality from 1990}

Our first application is to use the model database for 2016 and the changes in factor use, TFP, factor bias, cheaper capital, reduced income tax and labour force participation, that had been observed since 1990, to construct a corresponding representation of the US economy in 1990 . Focal in our analysis are changes in factor shares leading up to 2016, which are plotted in Figure 6, and which show the continuous decline in the low-skill labour share discussed previously. The corresponding growth in the skill share moderates after 2000, suggesting that the substitution for high-skill jobs has slowed and that automation is encroaching on skilled labour demand as well (Autor 2016, Beaudry et al. 2017). Associated with this is evidence of a modest growth trend in the capital share.

Other key influences over income distribution include labour force participation and rates of direct taxation. Labour force participation, as a proportion of the population, has fallen from 51 to 49 per cent since 1990, which seems modest, but this disguises a much larger fall amongst the low-skilled. When rising participation rates amongst professionals are accounted for (Tracey and Fels 2016) we estimate that low-skilled participation fell by four percentage points, reducing the earning power of low-income households. With respect to tax rates, notwithstanding much discussion of the Reagan and GW Bush tax cuts to high income earners, the evidence on federal tax rates from the Congressional Budget Office 
suggests only moderate declines in effective rates of tax on incomes to skill and capital. Our estimated rates are illustrated in Figure 7. We also consider the well-known decline in the cost of physical capital relative to other goods, which favours investment and income from physical capital, and changes in fiscal balance. In each case, the aggregate 1990-2016 shocks applied to the model are listed in Table 3. When all these shocks are imposed collectively the consequences for each household's share of population and disposable income can be compared across the two periods, as in Table 4, yielding the three-household Lorenz curves illustrated in Figure 8.

\subsection{Decomposition of Inequality Determinants 1990-2016}

Here we use the model to decompose the aggregate and distributional changes in the US economy into components due to the different determinants of change across the period. The shocks to the variables listed in Table 3 can be imposed both individually and collectively allowing the contribution of each to be quantified. The results are summarized in Table 5. The major contributors to the changes in GDP and real disposable income are, not surprisingly, factor use and total factor productivity. While the considerable relative expansion in the supply and use of high-skill labour militates toward greater equality, the shift in factor shares outweighs it, and aided by falling participation rates in the low-income household combined with reduced tax rates on professional and capital incomes, yields a modelled Gini coefficient that is higher by 10 per cent.

The corresponding decomposition of real incomes by household is summarized in Table 6 . These results show even more clearly that the drag on the real disposable income of the lowincome household is dominated by the change in factor bias. This household is the only one to lose from changes in factor bias and, also, the only one to lose from changes in participation rates and tax rates. Even though this technical change most favours skilled workers, the growth in real disposable income is greatest for the capital-owning household, principally because this household gains most from the comparatively high rate of capital accumulation and disproportionately from the rise in TFP.

\subsection{The Counterfactual: The Path With-Out Tech Bias}

By subdividing the back-cast shocks and constructing depictions of the economy for selected years since 1990 it is possible to chart a simulated course through 2016. It is then possible to construct this course such that there is no change in factor bias beyond 1990. All the other shocks from Table 3 apply in their sub-period versions, including those to TFP. The results 
from this exercise are shown in Figure 9. They illustrate the significance of tech bias in the path of the economy and, in particular, in the path of inequality and the welfare of the lowincome household. The results suggest that, in the absence of tech bias since 1990, and assuming the same level of TFP growth could have been achieved in its absence, the Gini coefficient would actually have fallen and the real consumption low-skill wage would have risen by two-thirds.

The ratio of financial wealth and GDP is an alternative inequality measure in that it contrasts the value of the capital that is mostly owned by the wealthier households with national income. Financial wealth grows with the accumulation of physical capital and with changes in the valuation of that capital that are based on expectations (equation 27). Relative to GDP the results suggest that this measure has increased considerably since 1990 and that a substantial contribution to this growth has been due to the effect on valuations of the advantage given to physical capital afforded by the bias component of technical change. As chosen techniques have become less intensive in low-skill labour, due to innovation, trade and competition changes, expected rates of return on capital have grown. Yet, at the same time, increased concentration of income in the high-saving households has tended to suppress financing rates, raising discounted present values.

\section{Implications of Prospective Automation in the US}

In looking ahead we construct a "central” projection over the coming two decades, around which we examine the paths of different inequality outcomes. The elements of this projection are given in Table 7. Factor supply changes are projected by imposing a population increment, drawn from the baseline UN projection, a tenth of which accrues to the professional household. Labour force participation rates, defined on populations, are held constant. The level of capital use is endogenous and allowed to expand so as to keep the expected rate of return on capital constant. TFP grows at the same annual rate as was achieved during 1990-2016 and, to reflect tech bias, factor shares change as illustrated in Figure 6. The low-skill labour share is simply extrapolated based on previous decades while no growth is introduced in the skill share to reflect a possible stand-off between the encroachment of automation on professional employment on the one hand and the creation of new professional jobs on the other (Autor 2016, Beaudry et al. 2017). The rise in the capital share is then a residual. The only other projected change is in the depreciation rate, which is 
raised from four to six per cent on the expectation that the rise in the IT proportion of the capital stock will increase the overall rate of obsolescence. ${ }^{14}$ This "central” projection is implemented under five alternative closures, in all of which there is no change in fiscal balance.

\subsection{Projection with no Policy Change}

No change in tax policy is assumed, along with downward rigidity of real, production, lowskill wages, reflecting minimum wage laws. The results for this case are shown in the first column of Table 8. Most notably, worker displacement raises the unemployment rate to 18 per cent and the Gini coefficient increases from 0.476 to 0.521 . There is a considerable net improvement in overall welfare, by 39 per cent, with the low-income household enjoying improvement by a much smaller 11 per cent. This overall improvement raises government collections at constant rates of tax, which makes affordable a rise in transfers, including unemployment benefits, from 8.1 to 10.6 per cent of GDP. This considerable overall prosperity gain also raises the financial wealth to GDP ratio from 3.5 to 4.7 . The increasingly stark differences in performance between the low-income and the other households, combined with the extraordinary unemployment, suggest corrective policy changes.

\subsection{Transfers to Stabilise Inequality}

The next step is to consider the expansion of transfers to the low-income household sufficiently to hold constant the Gini coefficient at its 2016 level. At issue, then, is how these transfers should be funded. We consider funding from two sources. The first option is a rise in the capital income tax rate, which reflects the dictum that the robots (or their owners) should be taxed. ${ }^{15}$ The second is the imposition of a federal tax on consumption expenditure. In each case nominal government expenditure on goods and services is retained exogenous, along with the fiscal deficit. ${ }^{16}$ Rises in transfers are then financed from increases in the respective tax rates.

\footnotetext{
${ }^{14}$ As indicated by Rognlie (2014), US Bureau of Economic Analysis data suggests that the depreciation and obsolescence rates for IT equipment and software are $18 \%$ and $43 \%$, respectively. Because the relative price of IT capital services has been falling, its share of capital value has grown only moderately, but its share of capital volume continues to grow rapidly. It is the latter that has most implications for the average rate of depreciation, and indeed for factor demand behaviour.

${ }^{15}$ This was famously suggested by Bill Gates in an interview with Quartz: https://qz.com/911968/bill-gates-therobot-that-takes-your-job-should-pay-taxes/.

${ }^{16}$ The fiscal deficit, and expenditure on goods and services, are held constant in real terms (relative to the GDP price, $P^{Y}$ ); not relative to GDP.
} 
Both taxes cause negative multiplier effects in this application. As the capital income tax rises, there is downward pressure on the net real rate of return and so the endogenous capital build-up is reduced, cutting aggregate demand and the employment of elastically supplied low-skill workers. This, in turn, requires a larger transfer to the low-skill household and therefore a further increase in the capital income tax rate. And so on. In the case of the consumption tax, a rise in its rate immediately affects the scale of transfers to low-skill households that are needed to stabilize the Gini. This rise in transfers then requires a further increase in the consumption tax rate. And so on.

The results are shown in the second and third columns of Table 8. They indicate that this multiplier effect is considerably more serious in the case of the capital income tax than it is with the consumption tax. The capital income tax curtails overall growth substantially and a rate increase of 17 percentage points is required. By contrast the consumption tax alternative requires only seven percentage points and it restores the original levels of performance in terms of capital, GDP and welfare growth. In both cases the scale of transfers, almost all to the low-income household, rises from eight per cent to almost 15 per cent of GDP. Financing from a consumption tax therefore seems less distortionary, maintaining the Gini while allowing considerably superior aggregate performance.

\subsection{Broadening the “Earned Income Tax Credit” System}

The alternative to allowing workers to be displaced at minimum wages and supported in unemployment via transfers is to keep them working at market-driven lower wages but to offer compensatory transfers. In practice this system is operational in the US, directed particularly at families with children (IRS 2017). We model a broadening of this policy that combines a simultaneous relaxation of minimum wage laws with transfers that are conditional on employment and sufficient to stabilize the Gini coefficient. Once again, the fiscal deficit and government expenditure on goods and services are set as exogenous and the transfers are financed by either a rise in the capital income tax rate or a rise in the consumption tax rate. The results are summarized in the final two columns of Table 8.

This policy option is superior to that with a minimum low-skilled wage because employment is larger and so, therefore, is the expected rate of return on physical capital, thus raising the eventual capital stock, output and income. The transfers, mainly to the low-income household, are larger in this case but unemployment benefit payments are smaller, leaving the total benefits paid at around the same percentage of GDP. Indeed, the imposed transfers due 
to all four interventionist options add little more than four percentage points of GDP to government revenue and expenditure. Here again, financing of the associated transfers from the tax on consumption expenditure, rather than capital income, is the source of further gains. The negative multiplier effect of the consumption tax, once again, proves smaller than for the capital income tax. Overall, then, the earned income tax credit system, with additional transfers financed by consumption tax, proves the superior option in response to further declines in the low-skill share of income and to population growth that is heavy in low-skill workers.

\subsection{Sensitivity to Departures from the “Central” Projection}

Because our central projection is merely an extrapolation of trends in factor shares, population and productivity, it carries no particular analytical weight. Here we examine variations around it in these three directions. The results are summarized in Figure 10, which has the "central" projection results indicated by diamond markers. Not surprisingly, the results are most sensitive to TFP growth. Since this "lifts all boats" strong growth in it can be sufficient to eliminate low-skill worker displacement, if not inequality. Nonetheless, the necessary TFP increase would need to be around 35 per cent, implying roughly twice the TFP growth rate achieved between 1990 and 2016. More concerning is the prospect of a continuation of the poor productivity performance of the last decade. This could lead to a very negative outcome for the economy as a whole, along with unemployment rates over 30 per cent. Still worse is the possibility that this poor productivity outcome is combined with a larger decline in the low-skill share of income and population growth that supplies predominantly low-skill workers.

\section{Conclusion}

Changes in the choice of technique since 1990 in key OECD are first reviewed, highlighting implications for productivity and factor bias. The productivity slowdown in the early 2000s is noted along with the already wisely discussed shift in factor shares away from low-skill labour toward skill and the smaller and more recent shift toward physical capital. An elemental three-household general equilibrium model is then used to quantify the links between real income and inequality on the one hand and changes in factor abundance, total factor productivity, factor bias, the relative cost of capital goods, labour force participation and the progressivity of the tax system on the other. In an application to the US, changes in 
factor bias are shown to have been the primary cause of the observed increase in inequality between 1990 and 2016.

The widely anticipated future twist away from low-skill labour toward capital is then examined, in combination with expected changes in population and its skill composition. With downward rigidity of low-skill wages the potential is identified for unemployment to rise to extraordinarily high levels, with possible exacerbation from low-skill intensive population growth and productivity growth that is no greater than that achieved since 1990. Indeed, the results suggest that productivity growth at twice the pace since 1990 would be needed to constrain unemployment, though even this would not slow the concentration of income. The superior policy response is shown to be a generalization of the US "earned income tax credit” system, with financing from taxes on consumption, rather than capital income.

\section{References}

Acemoglu, D. and D. Autor (2011), "Skills, tasks and technologies: Implications for employment and earnings", Chapter 12 in the Handbook of Labour Economics, Volume 4, Part B: 1043-1171. http://dx.doi.org/10.1016/S0169-7218(11)02410-5

Acemoglu, D. and P. Restrepo (2015), “The race between man and machine: implications of technology for growth, factor shares and employment”, NBER Working Paper No. 22252.

Acemoglu, D., D.H. Autor, D. Dorn, G. Hanson and B. Price (2016), "Import competition and the great US employment sag of the 2000s", Journal of Labor Economics, Vol. 34, No. S1, Part 2, January, pp. S141-S198.

Arora, V., R. Tyers and Y. Zhang (2015), "Reconstructing the savings glut: the global implications of Asian excess saving”, International Journal of Economics and Finance, Vol. 7, No. 7, pp. 19-42, July.

Autor, D. (2016), "Why Are There Still So Many Jobs? The History and Future of Workplace Automation”, Journal of Economic Perspectives, Summer, Vol. 29, No.3, pp. 3-30.

Autor D.H., D. Dorn and G. Hanson (2013, “The China syndrome: local labour market effects of import competition in the US”, American Economic Review, Vol. 103, No.6, pp.: 2121-68, October.

Autor, D.H., D. Dorn, L.F. Katz, C. Patterson and J. Van Reenen (2017a), "The fall of the labor share and the rise of superstar firms”, Working Paper, Massachusetts Institute of Technology.

(2017b), "Concentrating on the fall of the labor share”, CESifo Working Paper No. 6336. Available at SSRN:https://ssrn.com/abstract=2932777. 
Avent, R. (2016), The Wealth of Humans: Work Power and Status in the $21^{\text {st }}$ Century, New York: St Martin's Press.

Barrat, J. (2013), Our Final Invention: Artificial Intelligence and the End of the Human Era, New York: St Martin’s Press.

Beaudry, P., D.A. Green and B.M. Sand (2017), “The great reversal in the demand for skill and cognitive tasks." Journal of Labor Economics, Journal of Labor Economics, 34, no.S1 (Part 2, January 2016): S199-S247.

Berman, E., J. Bound and Z. Griliches (1994), "Changes in the demand for skilled labour within US manufacturing: evidence from the annual survey of manufactures", Quarterly Journal of Economics, Vol.109, No. 2, pp. 367-397.

Boshara R, Emmons WR and Noeth BJ (2015), “The demographics of wealth: How age, education and race separate thrivers from strugglers in today's economy”, Federal Reserve Bank of St. Louis, online available at https://www.stlouisfed.org/householdfinancial-stability/the-demographics-of-wealth

Bound, J. and G. Johnson (1992), "Changes in the structure of wages in the 1980s: an evaluation of alternative explanations”, American Economic Review, Vol. 82, No. 3, pp. 371-392.

Borjas, G.J. and V.A. Ramey (1994), "The relationship between wage inequality and international trade”, in J.H. Bergtrand, T.F. Cosimano, J.W. Houk and R.G. Sheehan (eds), The Changing Distribution of Income in an Open US Economy, Amsterdam: North Holland.

Brynjolfsson, E. and A. McAfee (2011), Race Against The Machine, Digital Frontier Press.

Congressional Budget Office (2017), An Update to the Budget and Economic Outlook: 2017 to 2027, US Government, Washington DC, June.

Das, S. (2016a), The Age of Stagnation:Why Perpetual Growth Is Unattainable and the Global Economy Is in Peril, Prometheus Books, 9 February, 285 pp. (2016b), "Workers will simply try to survive, rather than prosper, as tech takes over the economy”, Marketwatch.com, Opinion, 24 October.

Ezrachi, A. and M.E. Stucke (2016), Virtual Competition: The Promise and Perils of the Algorithm-Driven Economy, Cambridge MA: Harvard University Press.

Feenstra, R.C., R. Inklaar and M.P. Timmer (2015), “The next generation of the Penn World Tables”, American Economic Review, Vol. 105, No. 10, pp. 3150-3182, at www.ggdc.net/pwt.

Fleisher, B., H. Li and M.Q. Zhao (2010), "Human capital, economic growth, and regional inequality in China”, Journal of Development Economics, Vol. 92, Issue 2, pp.215231.

Ford, M. (2015), Rise of the Robots: Technology and the Threat of a Jobless Future, New York: Basic Books.

(2016), “Is American growth over?” The Huffington Post, 28 January.

Francois, J.F. and D. Nelson (1998), “Trade, technology and wages: general equilibrium mechanics”, Economic Journal, Vol. 108, Issue 450, pp.1483-99. 
Goos, M., A.S. Manning and A. Salomons (2014), “Explaining job polarization: routinebiased technological change and offshoring”, American Economic Review, Vol. 104, No. 8, pp. 2509-26.

Gordon, R.J. (2014), “The turtle’s progress: secular stagnation meets the headwinds”, Chapter 3 in Teulings and Baldwin (2014).

(2015), The Rise and Fall of American Growth: The U.S. Standard of Living Since the Civil War, Princeton University Press.

Gregory, R.G. (1993), “Aspects of Australian and US living standards: the disappointing decades 1970-1990”, Economic Record, Vol. 69, Issue 1, pp. 61-76.

Groningen Growth and Development Centre (2013), The Penn World Tables 8.0: TFP at Constant National Prices $(2005=1)$, 2011. Data-Planet ${ }^{\mathrm{TM}}$ Statistical Ready Reference by Conquest Systems, Inc. [Data-file]. Dataset-ID: 071-001-013, http://dx.doi.org/10.6068/DP141761C62519.

Kanbur, R., Y. Wang and X. Zhang (2017), “The great Chinese inequality turnaround”, BOFIT Discussion Paper 6-2017, Band of Finland Institute for Economies in Transition, Helsinki, online available at https://helda.helsinki.fi/bof/bitstream/handle/123456789/14667/dp0617.pdf?sequence=1

Haskel J., R.Z. Lawrence, E.E. Leamer and M.J. Slaughter (2012), “Globalization and U.S. Wages: Modifying Classic Theory to Explain Recent Facts”, Journal of Economic Perspectives, American Economic Association, Vol. 26, Issue 2, pp. 119-40, Spring.

Helpman, E., O. Itskhoki and S.J. Redding (2010), "Inequality and Unemployment in a Global Economy,” Econometrica, Vol. 78, Issue 4, pp. 1239-83.

Hemous, D. and M. Olsen (2014), "The rise of the machines: Automation, horizontal innovation and income inequality," online available at https://www.brown.edu/academics/economics/sites/brown.edu.academics.economics/f iles/uploads/rise_machines_paper_feb16.pdf

IMF (2017), Financial Data, International Monetary Fund, Washington DC, https://www.imf.org/external/data.htm\#financial.

Internal Revenue Service (2017), Earned Income Tax Credit (EITC), https://www.irs.gov/credits-deductions/individuals/earned-income-tax-credit.

Jin, Y. (2011), “Income inequality, consumption and social-status seeking”, Journal of Comparative Economics 39,191-204.

Khanna, P. (2016), Connectography: Mapping the Global Network Revolution, NY: Random House, 496pp.

Kho, D., R. Santaeulalia and Y. Zheng (2016), "Labour share decline and intellectual property products capital”, Working Papers 927, Barcelona Graduate School of Economics, February.

Krugman, P. (1995), “Growing world trade: causes and consequences”, Brookings Papers, 1: 327-377.

Kurzweil, R. (2005), The Singularity is Near, New York: Viking Books. 
Leamer, E.E. (1996), "Wage inequality from international competition and technological change: theory and country experience,” American Economic Review, Vol. 86, No.2, pp. 309-14, May.

Lo, S. and K. Rogoff (2015), "Secular stagnation, debt overhang and other rationales for sluggish growth, six years on”, BIS Working Paper No.482, Bank for International Settlements, Monetary and Economic Department, January.

McKibbin, W.J. and P. Wilcoxen (1995), "The theoretical and empirical structure of the GCubed model”, Economic Modelling, Elsevier, 16(1): 123-148, January.

Moazed, A. and N.L. Johnson (2016), Modern Monopolies: What it Takes to Dominate the $21^{\text {st }}$ Century Economy, New York: St Martin’s Press.

Mokyr, J. (2013), “Is technological progress a thing of the past?” VOX, 8 September.

Mokyr, J., C. Vickers and N.L. Ziebarth (2015), "The history of tech anxiety and the future of economic growth: is this time different?” Journal of Economic Perspectives, Vol. 29, No. 3, pp. 31-50.

Nordhaus, W.D. (2015), “Are we approaching an economic singularity? Information technology and the future of economic growth”, NBER Working Paper No. 21547, issued September 2015, rev January 2016.

OECD (2012), “Labour Losing to Capital: What Explains the Declining Labour Share?” in OECD Employment Outlook 2012, OECD Publishing, Paris. DOI: http://dx.doi.org/10.1787/empl_outlook-2012-4-en.

(2015), Income Distribution and Poverty Database, Paris: access via: http://stats.oecd.org/Index.aspx?DataSetCode=IDD

Pichelmann, K. (2015), “When 'secular stagnation’ meets Piketty’s capitalism in the 21st century: growth and inequality trends in Europe reconsidered”, European Commission Economic Papers, No 551, June.

Pierce, J.R. and P.K. Schott (2012), “The surprisingly swift decline of U.S. manufacturing employment”, American Economic Review, Vol. 106, No. 7, pp. 1632-62.

Piketty, T. (2014), Capital in the Twenty-First Century, Cambridge, MA: The Belknap Press of Harvard University Press.

Piketty, T. and G. Zucman (2014), "Capital is back: wealth-income ratios in rich countries 1700-2010,” The Quarterly Journal of Economics: 1255-1310.

Pomerleau, K. and A. Lundeen (2014), “Summary of Latest Federal Income Tax Data”, Tax Foundation, 22 December, http://taxfoundation.org/article/summary-latest-federalincome-tax-data-0, accessed 19092016.

Rognlie, M. (2014), “A note on Piketty and diminishing returns to capital”, MIT and Northwestern University, June. (2015), "Deciphering the fall and rise in the net capital share: accumulation, or scarcity?” Brookings Papers on Economic Activity, Spring: 1-69.

Schneider, M.P.A. and Tavani, D. (2016), “A tale of two Ginis in the US, 1921-2012”, International Review of Applied Economics, Vol. 30, Issue 6, pp. 677-692. DOI:10.1080/02692171.2016.1173654. 
Summers, L.H. (2014), “Secular stagnation and monetary policy”, Federal Reserve Bank of St. Louis Review, Second Quarter, Vol. 98, No. 2, pp. 93-110. (2016), "The age of secular stagnation: what it is and what to do about it", Foreign Affairs, March-April, pp. 2-9.

Susskind, D. (2017), “A model of technological unemployment”, Balliol College Oxford.

Susskind, R. and D. Susskind (2015), The Future of the Professions: How Technology will Transform the work of Human Experts, UK: Oxford University Press.

Timmer, M.P., E. Dietzenbacher, B. Los, R.R. Stehrerand G.J. de Vries (2015), “An Illustrated User Guide to the World Input-Output Database: the Case of Global Automotive Production”, Review of International Economics, Vol. 23, Issue 3, pp. 575-605.

Tokarick, S. (2005), "Quantifying the impact of trade on wages: the role of non-traded goods”, Review of International Economics, Vol. 13, Issue 5, pp. 841-860.

Tracey, M.R. and J. Fels (2016), “70 is the new 65: demographics still support lower rates for longer”, PIMCO In Depth, February, Pacific Investment Management Company, Newport Beach, CA.

Tyers, R. and Y. Yang (1997), "Trade with Asia and skill upgrading: effects on labor markets in the older industrial countries", Review of World Economics, Vol. 133, No. 3, pp. 383-418, September. (2000), “Capital-Skill Complementarity and Wage Outcomes Following Technical Change in a Global Model”, Oxford Review of Economic Policy, Vol. 16, Issue 1, pp. 23-41.

Winchester, N. and D. Greenaway (2007), "Rising wage inequality and capital-skill complementarity”, Journal of Policy Modeling, Vol. 29, Issue 1, pp. 41-54.

Wood, A. (1994), North-South Trade, Employment and Inequality, Oxford: Clarendon Press.

Zhou, Y. (2016), “Human capital, institutional quality and industrial upgrading: global insights from industrial data”, Economic Change and Restructuring, first online, doi:10.1007/s10644-016-9194-x.

Zhou, Y. and L. Song (2016), "Income inequality in China: causes and policy responses”, China Economic Journal, Vol. 9, Issue 2,pp. 186-208.

Zhou, Y. and R. Tyers (2017), “Automation and inequality in China”, CAMA Working Paper Vol: 59/2017, Australian National University. 
Figure 1. Income Gini Coefficients, Key OECD Countries

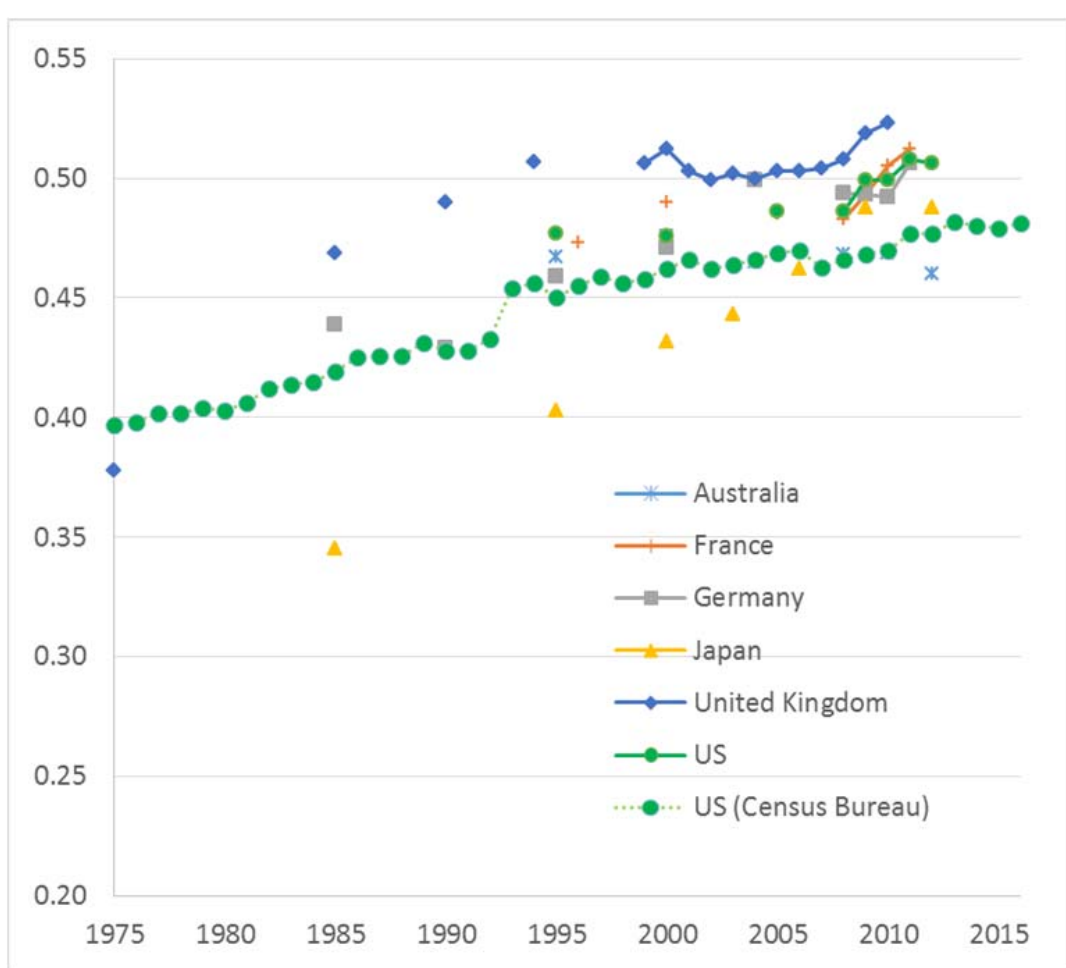

Source: Unless otherwise stated, OECD Income Distribution Database (OECD 2015). The single continuous series is from the U.S. Census Bureau, Current Population Survey, Annual Social and Economic Supplements.

Figure 2. Total factor productivity, 1970-2014

(United States, United Kingdom, Australia, OECD overall)

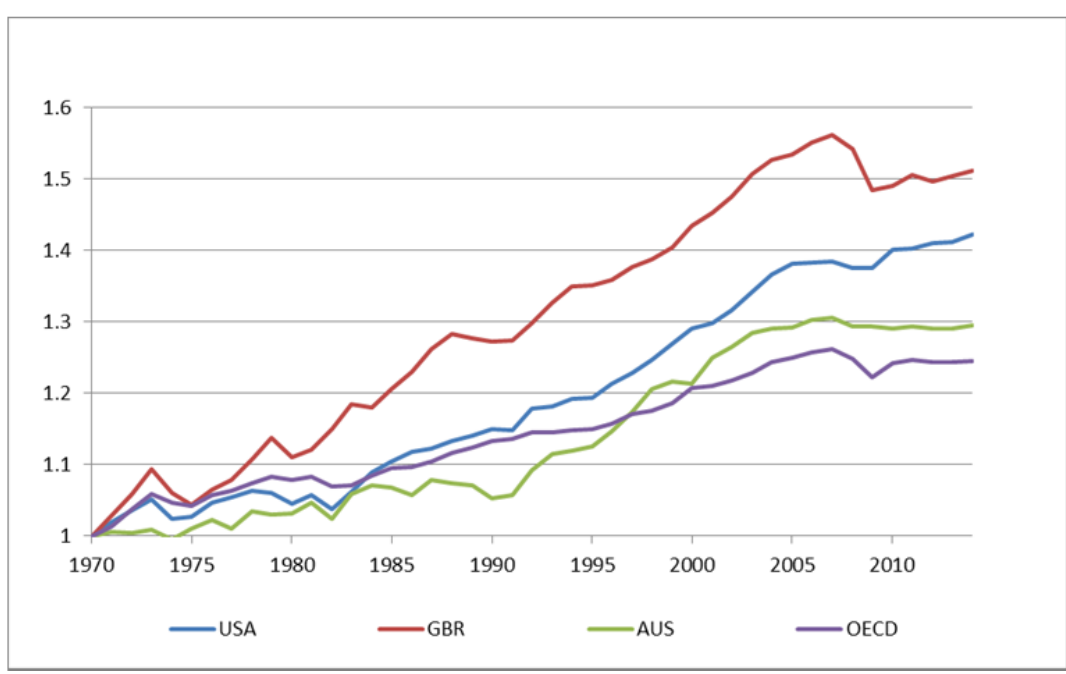

Source: Penn World Tables, international comparisons of production, income and prices, version 9.0. TFP is the portion of output change not explained by the quantities of inputs used in production and is reported at constant national prices (2011=1). We normalize the data to set TFP in 1970 at unity. 
Figure 3. Value Added Shares of Primary Factors (Capital, Labour, and Skill), United States, 1995-2008
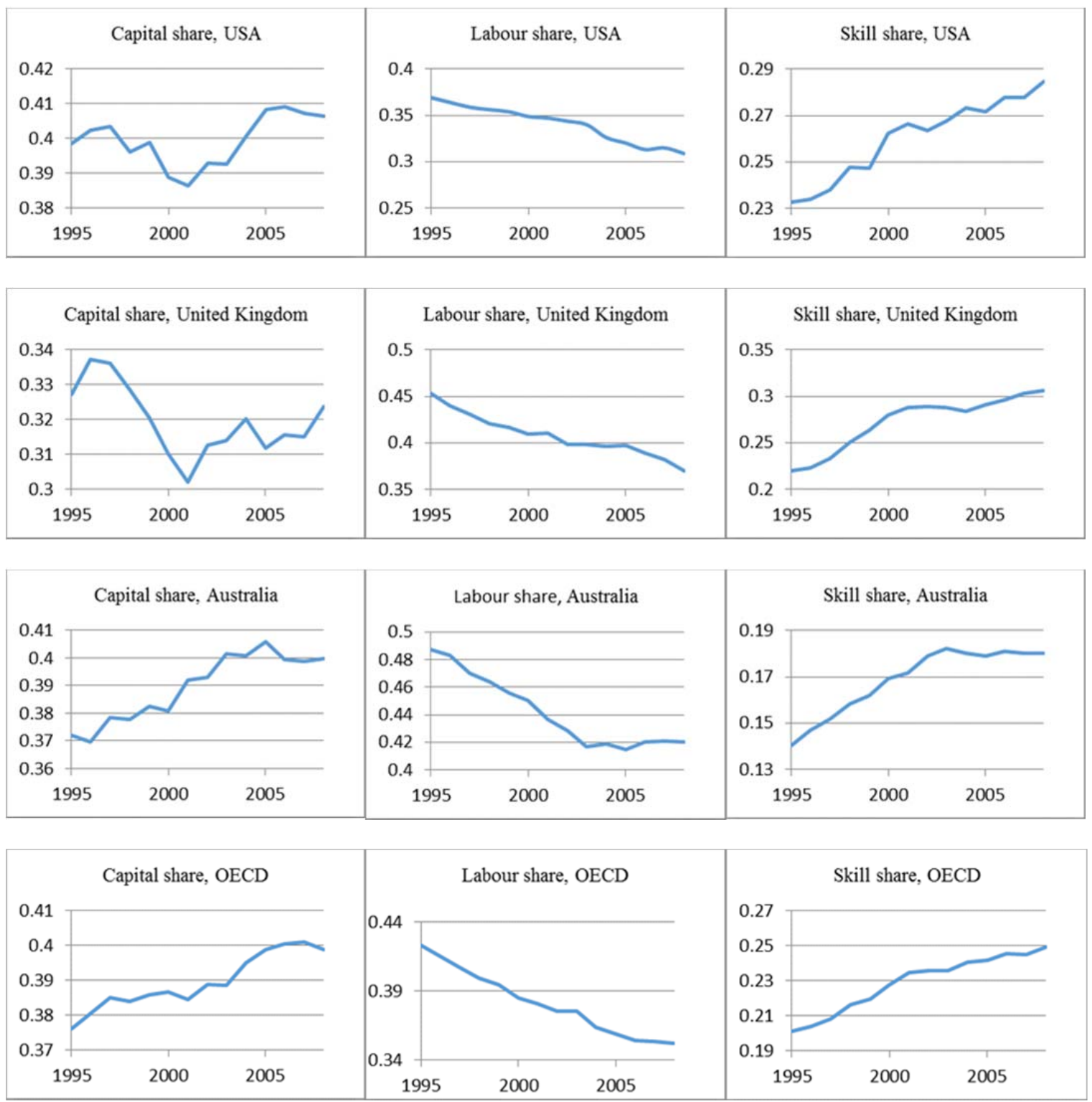

Source: Socio Economic Accounts, World Input Output Database, 2013 Release (Timmer et al. 2015)

Note: The capital share is calculated as the share of payment for capital in value added; labour share is the share of payment to medium- and low-skilled persons in value added; skill share is the share of payment to highskilled persons in value-added. Labour skill types are classified on the basis of educational attainment levels as defined in the International Standard Classification of Education (ISCED): low-skilled (ISCED categories 1 and 2), medium-skilled (ISCED 3 and 4) and high-skilled (ISCED 5 and 6). Capital compensation is derived as a residual and defined as gross value added minus labour income. Hence it is the gross compensation for capital, including profits and depreciation allowances. Because of its derivation as a residual, it reflects the remuneration for capital in the broadest sense. This does not include only traditional reproducible assets such as machinery and buildings, but it also includes non-reproducible assets. Examples are mineral resources and land, intangible assets (such as R\&D knowledge stocks, software, databases, brand names and organizational capital) and financial capital. 


\section{Figure 4. Trends in Real Worker Incomes in the United States}
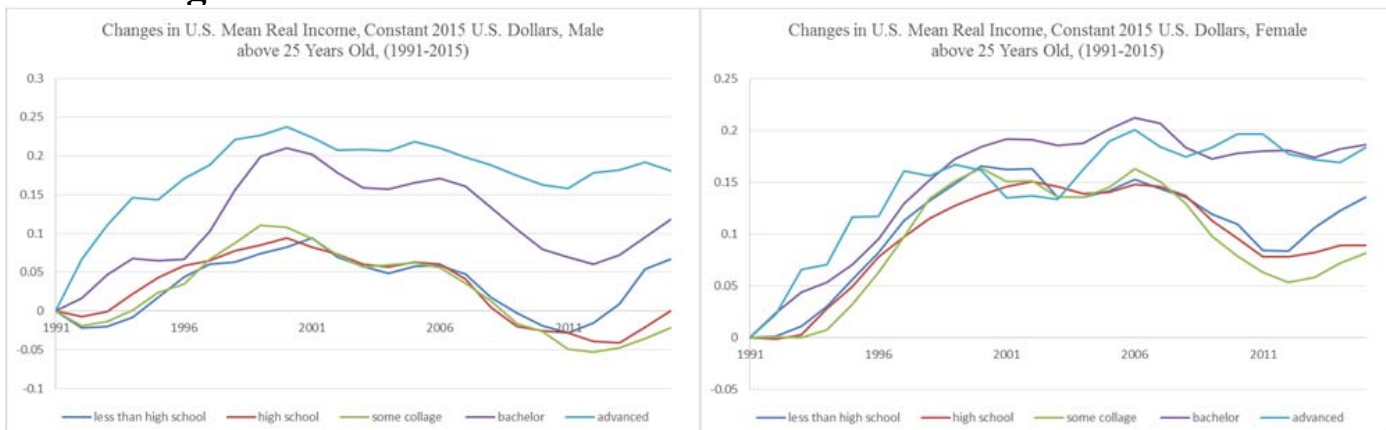

Source: Mean incomes in constant 2015 U.S. dollars by educational attainment based on Table P-18-

Educational Attainment, People 25 Years Old and Over by Mean Income and Sex, 1991 to 2015, the U.S.

Bureau of the Census.

Note: Cumulative percentage changes are shown relative to 1991 means. These are adjusted for price inflation, money earnings for working males and females (aged 25 and above) by educational cohort in terms of the highest level of education attained. Changes along the y-axis are log changes (which approximate percentage changes), smoothed to three-year moving averages to eliminate occasional annual volatility. Less than high school and some high school workers correspond to low-skill workers; high school grad and some college correspond to medium-skill workers; college grad and more than college correspond to high-skill workers.

\section{Figure 5. Population, Human Capital and Employment in the US}

(Indices 1990=100)

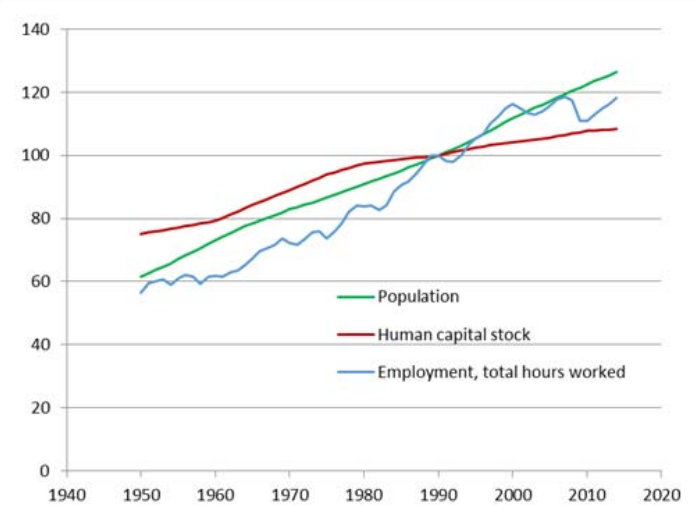

Source: Penn World Tables (Feenstra et al. 2015). The human capital index is based on years of schooling and returns to education; see "Human Capital" in PWT9.

\section{Figure 6. Factor Shares of Value Added in the US}

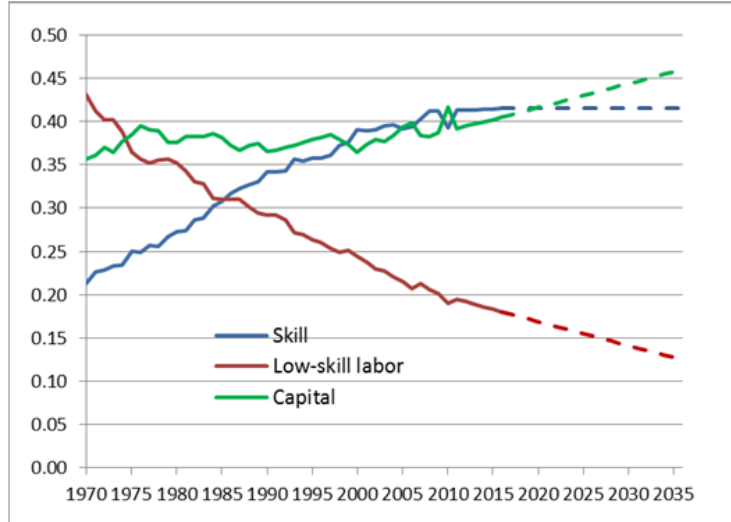

Source: Authors' calculations based on the Penn World Tables (Feenstra et al. 2015) and Socio Economic Accounts, World Input Output Database, 2013 Release (Timmer et al. 2015), along with employment and wage data from FRED. Solid lines indicate historical data. Broken lines indicate extrapolations used in the prospective analysis. 


\section{Figure 7: Approximate Effective Federal Tax Rates, US \% ${ }^{a}$}

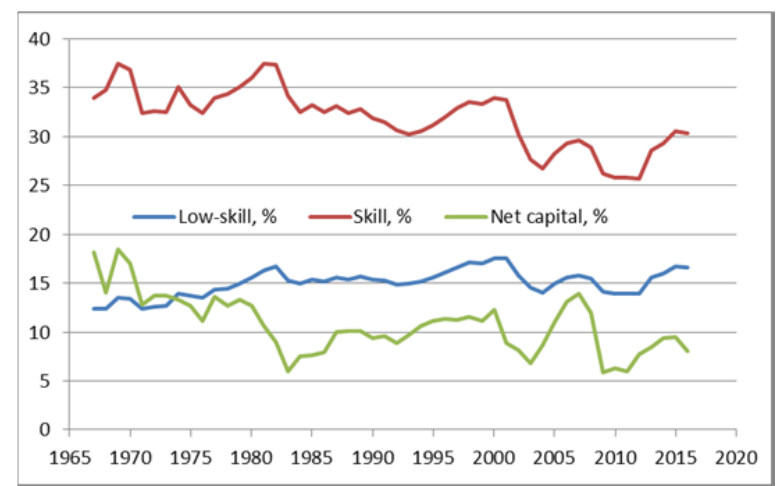

Source: Authors' calculations based on revenues from Congressional Budget Office (2017) and tax bases from the World Input-Output Database (Timmer et al. 2015). Capital consumption from FRED is deducted from gross capital income to form the capital income tax base and estate tax revenue is added to other capital tax revenue. The low-skill and high-skill income tax bases are payments to these factors recorded in the InputOutput Database. Payroll tax revenue is added to that from household income taxes which are then split on the assumption that the low-skill rate, inclusive of payroll tax, has averaged $15 \%$.

\section{Figure 8: Simulated Three-Household Lorenz Curves, 1990 and $2016{ }^{\mathrm{a}}$}

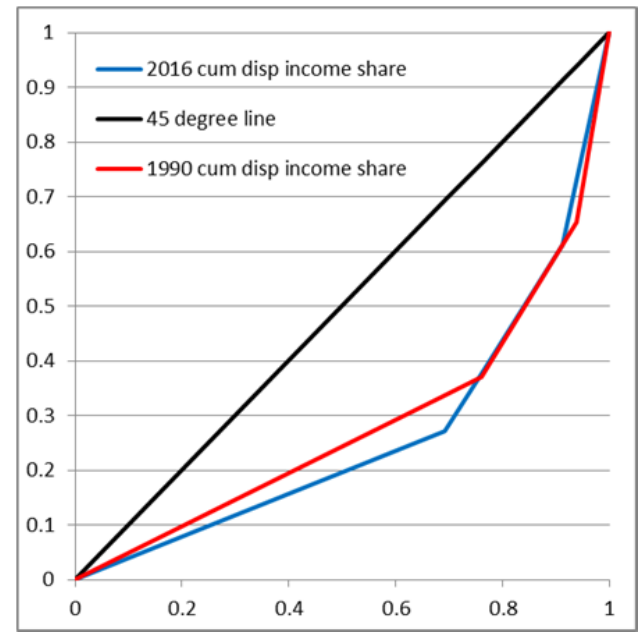

a This summarises the results of the simulated response of the economy to the collective shocks indicated in Table 3. It mirrors the shares indicated in Table 4.

Source: Solutions to the model described in the text. 
Figure 9. Decomposition Results: Key Effects of Tech Bias in the US

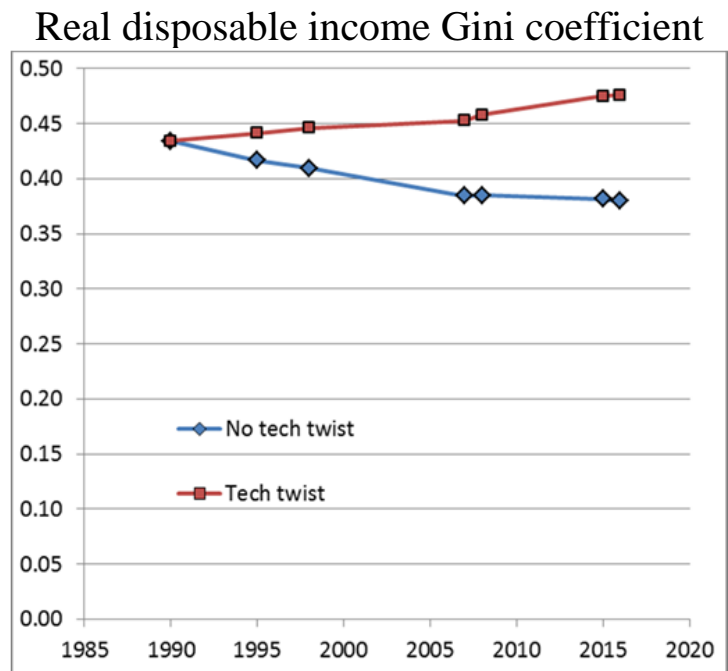

Real low-skill consumption wage, 2016 US\$ '000

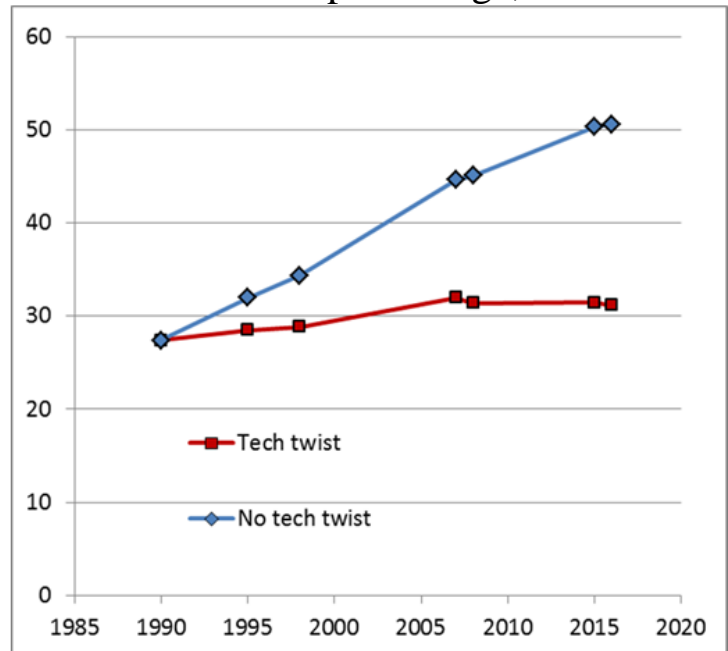

Financial wealth to GDP ratio

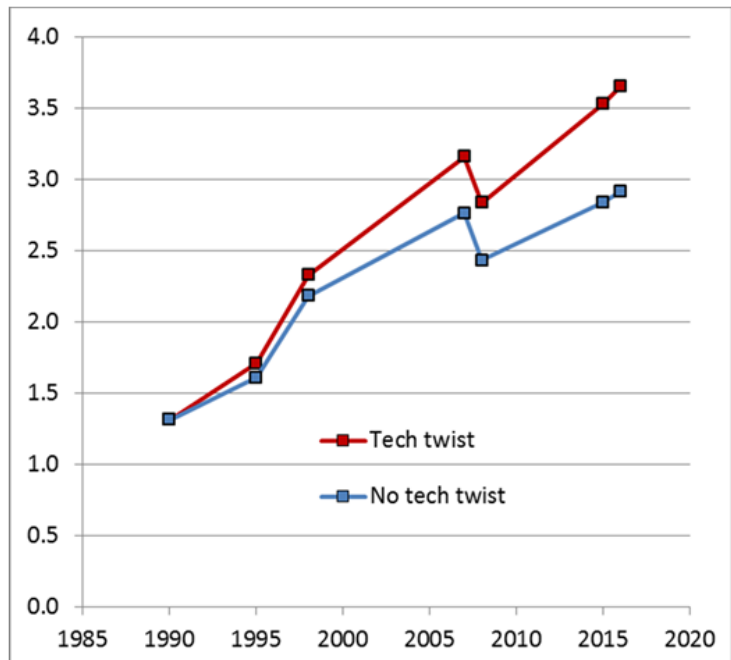

Source: Back-casts from 2016 using the model described in the text. 


\section{Figure 10: Sensitivity to Departures from the Central Projection ${ }^{\mathrm{a}}$}

(Per cent changes in noted variables)

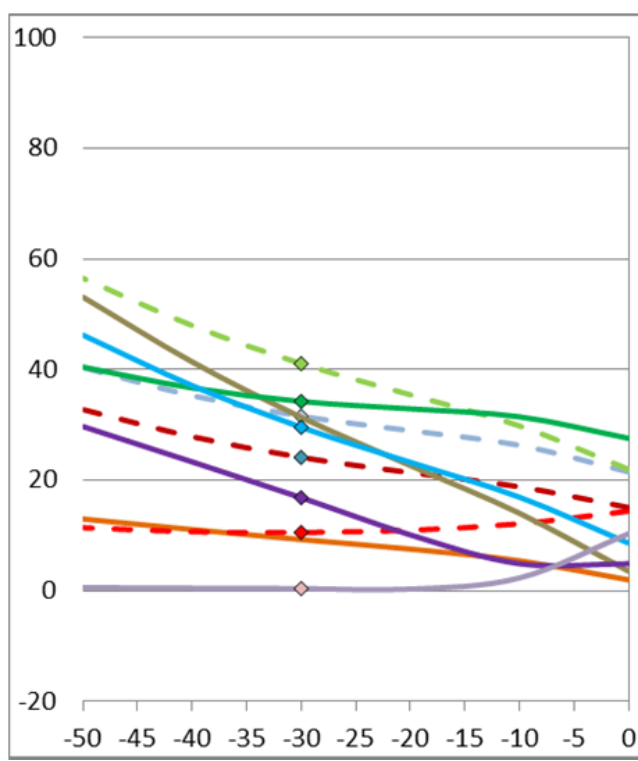

$\%$ share of low-skill labour in value added

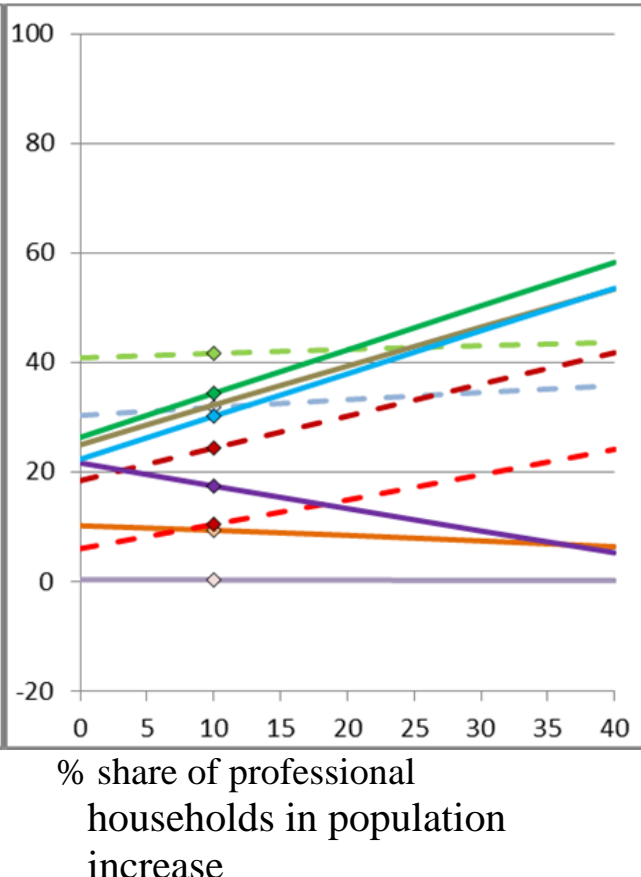

increase

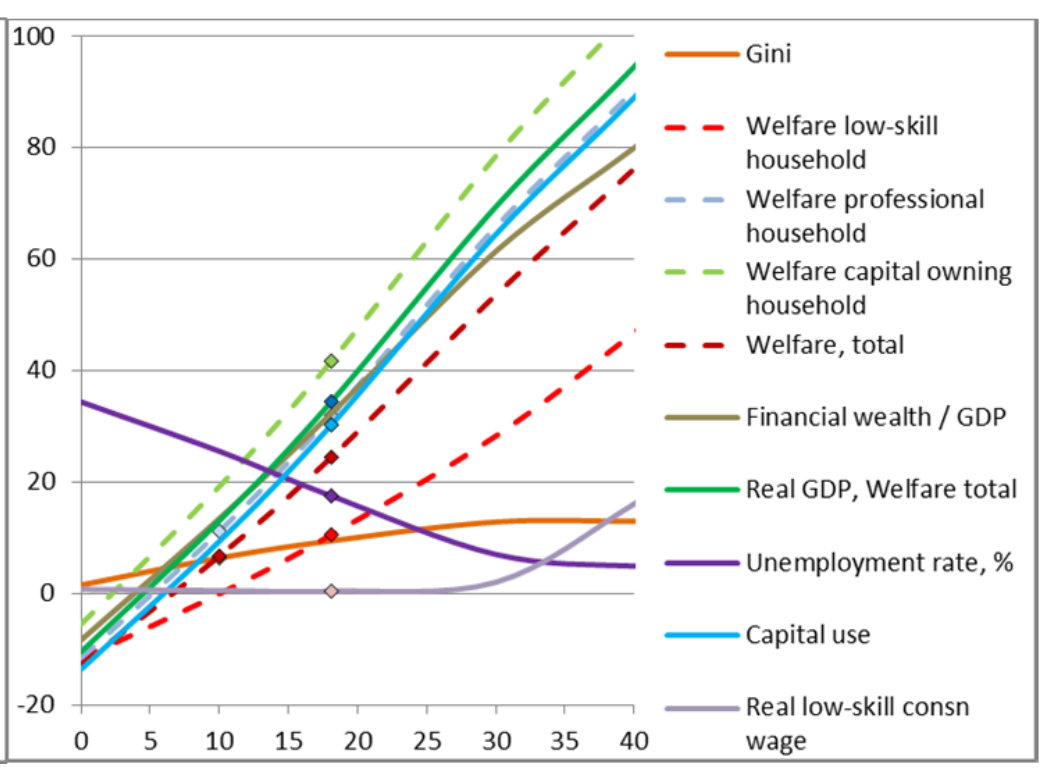

$\%$ increase in total factor productivity wage

a These graphs represent sensitivity to changes in factor shares, the composition of the population increase and total factor productivity of the "central” projection shocks documented in Table 8. In all simulations the closure is as for the first column of that table, reflecting no policy change. Minimum low-skill wage rates apply with flexibility upward when the unemployment rate is at its lower bound of $4.9 \%$. The per cent changes are shown for all variables except the rate of unemployment. The actual level of the unemployment rate is shown in percentage points.

Source: Solutions to the model described in the text. 
Table 1. Earnings Gaps between Skill Groups as \% of Income to the Low Skilled

\begin{tabular}{lcccc}
\hline & \multicolumn{2}{c}{$\begin{array}{c}\text { Low to medium skill } \\
\text { (as \% of low skill earnings) }\end{array}$} & \multicolumn{2}{c}{$\begin{array}{c}\text { Medium to high skill } \\
\text { (as \% of low skill earnings) }\end{array}$} \\
Australia & $\mathbf{2 0 0 2}$ & $\mathbf{2 0 1 4}$ & $\mathbf{2 0 0 2}$ & $\mathbf{2 0 1 4}$ \\
Germany & 22 & 14 & 28 & 32 \\
Korea & 30 &. & 33 &. \\
United Kingdom & 41 & 14 & 31 & 33 \\
United States & 47 & 32 & 39 & 36 \\
OECD & 52 & 37 & 48 & 50 \\
\hline
\end{tabular}

(full-time 25-64 year-old employees)

Source: Authors’ calculations based on data from OECD Employment Outlook, 2014 and 2016.

Note: Data on mean incomes are not available. Earnings by skill (or education levels) refer to mean annual earnings of full-time for 25-64 year-old employees. Earnings gaps between medium-skilled and low-skilled employees are calculated as the difference between mean earnings of medium-skilled employees and low-skilled employees relative to mean earnings of low-skilled employees; earnings gaps between high-skilled and mediumskilled employees are calculated as the difference between mean earnings of high-skilled employees and medium-skilled employees relative to mean earnings of low-skilled employees. The skill levels are based on the International Standard Classification of Education (ISCED, 2011). Low (skills) corresponds to less than upper secondary ISCED levels 0, 1, 2 (Less than primary, primary and lower secondary education). Medium (skills) corresponds to upper secondary and post-secondary non-tertiary ISCED levels 3 (including partial level completion), and ISCED 4 (Upper secondary and post-secondary non-tertiary education). High (skills) corresponds to tertiary ISCED levels 5, 6, 7 and 8 (short-cycle tertiary education, bachelors or equivalent level, masters or equivalent level, doctoral or equivalent level).

Table 2: Stylised Household Factor Ownership Shares Used in Modelling

\begin{tabular}{lccc}
\hline Households & Low-skill labour & Primary factors & Skill \\
Low-income & 0.95 & 0.01 & 0.10 \\
Professional & 0.04 & 0.70 & 0.20 \\
Capital-owning & 0.01 & 0.29 & 0.70 \\
All households & 1.00 & 1.00 & 1.00 \\
\hline
\end{tabular}

Source: These are highly stylized but representative of data on wealth shares from Schneider and Tavani (2016) and Boshara et al. (2015). 
Table 3: Decomposition of Past Aggregate Performance Changes in the US: Forward Shocks from 1990 to $2016^{a}$

\begin{tabular}{lcc}
\hline Variable shocked, $\mathbf{1 9 9 0}$ to $\mathbf{2 0 0 8}$ & Shock, \% change \\
\hline Factor use: & Low-skill labour & 6.4 \\
& Skill & 91.3 \\
Capital & 79.0 \\
Total factor productivity & 24.2 \\
Factor shares: & Low-skill labour & -38.4 \\
& Skill & 21.4 \\
Capital & 10.6 \\
Cheaper capital relative to goods & -16.9 \\
Power of income tax rates & \\
$\quad$ Low-skill labour income & 1.0 \\
Skill income & -1.1 \\
Capital income & -1.2 \\
Government saving (negative) & \\
Labour force participation rates & 9.5 \\
Low skill labour & \\
Skill & -7.9 \\
Unemployment rate & 13.3 \\
\hline
\end{tabular}

a The decomposition is achieved by shocking these variables individually and collectively. All shock variables are available for intermediate years and some intermediate shocks are illustrated graphically. b This is a shock to the fiscal deficit, measured relative to the GDP price, $P^{Y}$.

c The changes in participation rates affect the per capita measures in the modelling. They are inferred from the skilled participation results of Tracey and Fels (2016) and the overall participation rate series from FRED.

Sources: Factor use, factor share and total factor productivity changes are from Socio Economic Accounts, World Input Output Database, 2013 Release (Timmer et al. 2015) and the Penn World Tables Database (Feenstra et al. 2015). The relative capital goods price compares capital with GDP prices from FRED and the tax rates are interpretations from IMF, World Economic Outlook Database and Pomerleau and Lundeen (2014).

Table 4: Household Population and Disposable Income Shares, 1990 and 2016

\begin{tabular}{|c|c|c|c|c|}
\hline \multirow[t]{2}{*}{ Shares of totals, \% } & & \multicolumn{3}{|c|}{ Households } \\
\hline & & Low income & Professional & Capital owning \\
\hline \multirow[t]{2}{*}{ Population } & 1990 & 76 & 18 & 6 \\
\hline & 2016 & 69 & 22 & 9 \\
\hline \multirow[t]{2}{*}{ Disposable income } & 1990 & 37 & 28 & 35 \\
\hline & 2016 & 27 & 34 & 39 \\
\hline
\end{tabular}

a These represent changes in shares in response to the shocks listed in Table 3. They provide the basis for the Lorenz curves in Figure 8 and the period change in the Gini coefficient.

Source: Model database and back-cast simulation to 1990. 
Table 5: Decomposition of Aggregate Performance Changes in the US - 1990 to $2016{ }^{a}$

\begin{tabular}{|c|c|c|c|c|c|c|c|c|c|}
\hline $\begin{array}{l}\text { Per cent change } \\
2016 \text { over } 1990\end{array}$ & $\begin{array}{c}\text { Factor } \\
\text { use }\end{array}$ & TFP & $\begin{array}{l}\text { Factor } \\
\text { shares }\end{array}$ & $\begin{array}{l}\text { Cheaper } \\
\text { capital }\end{array}$ & $\begin{array}{l}\text { Fiscal } \\
\text { deficit }\end{array}$ & $\begin{array}{c}\text { Lower } \\
\text { tax } \\
\text { rates }\end{array}$ & $\begin{array}{l}\text { Participation \& } \\
\text { unemployment }\end{array}$ & $\begin{array}{c}\text { Total } \\
\text { effects }\end{array}$ & $\begin{array}{l}\text { Av growth } \\
\text { rate, } \% / y r\end{array}$ \\
\hline Real gross investment \& saving & 61.5 & 50.2 & 24.8 & 16.7 & -5.3 & 3.6 & 0.8 & 152 & 4.5 \\
\hline Net real rate of return & -44.1 & 63.0 & 19.3 & 64.9 & 0.0 & -0.1 & 0.7 & 104 & 3.4 \\
\hline Real financing interest rate & -44.6 & 8.9 & -4.7 & 8.3 & 1.1 & -1.0 & 0.0 & -31.9 & -1.8 \\
\hline Real consumption low-skill wage ${ }^{b}$ & 37.6 & 14.9 & -38.4 & 0.0 & 0.0 & 0.0 & -0.4 & 13.7 & 0.6 \\
\hline Real consumption high-skill wage ${ }^{b}$ & -27.3 & 29 & 21.5 & 0.0 & 0.0 & 0.0 & 0.2 & 23.8 & 1.0 \\
\hline Real disposable income & 71.5 & 23.8 & 0.0 & -0.3 & 0.0 & 0.8 & 0.1 & 96.0 & 3.3 \\
\hline Real GDP & 70.4 & 24.2 & 0.0 & 0.0 & 0.0 & 0.0 & 0.3 & 94.9 & 3.2 \\
\hline Real per capita disposable income & 37.3 & 23.6 & -0.4 & -0.4 & 0.0 & 0.7 & -6.8 & 54.0 & 2.1 \\
\hline Gini coefficient & -22.1 & 0.3 & 25.3 & -0.2 & 0.0 & 1.1 & 5.3 & 9.6 & 0.4 \\
\hline Financial wealth/GDP & 75.5 & 16.5 & 25.4 & 63.0 & -5.1 & 3.5 & 0.2 & 179.0 & 5.0 \\
\hline
\end{tabular}

a All but the final column show forward \% changes from 1990. Changes in the rate of return and the financing rate are percentages of original rates, not percentage points.

b Real consumption wages are nominal wages defined initially relative to the GDP price, $P^{Y}$, divided by the consumer price, $P^{C}$, also defined relative to $P^{Y}$.

Source: Back-casting using the model described in the text. 
Table 6: Decomposition of Household Income Changes in the US - 1990 to $2016^{\mathrm{a}}$

\begin{tabular}{|c|c|c|c|c|c|c|c|c|c|}
\hline $\begin{array}{l}\text { Per cent } \\
\text { change } \\
2016 \text { over } \\
1990 \\
\end{array}$ & & $\begin{array}{c}\text { Factor } \\
\text { use }\end{array}$ & TFP & $\begin{array}{l}\text { Factor } \\
\text { shares }\end{array}$ & $\begin{array}{l}\text { Cheaper } \\
\text { capital }\end{array}$ & $\begin{array}{c}\text { Lower } \\
\text { tax } \\
\text { rates }\end{array}$ & $\begin{array}{c}\text { Participation \& } \\
\text { unemployment }\end{array}$ & $\begin{array}{c}\text { Total } \\
\text { effects }\end{array}$ & $\begin{array}{l}\text { Av growth } \\
\text { rate, } \% / y r\end{array}$ \\
\hline \multirow{4}{*}{$\begin{array}{l}\text { Real } \\
\text { disposable } \\
\text { income }\end{array}$} & Low income & 52.5 & 17.7 & -24.9 & 0.0 & -1.2 & -0.2 & 43.9 & 1.7 \\
\hline & Professional & 87.4 & 27.9 & 15.5 & -0.1 & 3.4 & 0.3 & 134 & 4.1 \\
\hline & Capital-owning & 78.8 & 26.9 & 12.9 & -0.8 & 2.1 & 0.3 & 120 & 3.8 \\
\hline & Total & 71.5 & 23.8 & 0.0 & -0.3 & 0.8 & 0.1 & 96.0 & 3.3 \\
\hline \multirow{4}{*}{$\begin{array}{l}\text { Real } \\
\text { disposable } \\
\text { income per } \\
\text { capita }\end{array}$} & Low income & 44.0 & 17.5 & -25.2 & -0.1 & -1.1 & -10.9 & 24.2 & 1.0 \\
\hline & Professional & -12.7 & 27.6 & 15.1 & -0.2 & 1.9 & 17.8 & 49.5 & 1.9 \\
\hline & Capital-owning & -19.3 & 26.7 & 12.5 & -0.6 & 1.2 & 0.2 & 20.6 & 0.9 \\
\hline & Total & 37.3 & 23.6 & -0.4 & -0.4 & 0.7 & -6.8 & 54.0 & 2.1 \\
\hline
\end{tabular}

a All but the final column show forward \% changes from 1990.

b Disposable income is defined relative to the GDP price, $P^{Y}$, and it is here divided by the consumer price, $P^{C}$, also defined relative to $P^{Y}$.

Source: Back-casting using the model described in the text. 
Table 7: “Central” Projection Shocks for the US: 2016 to $2036^{\text {a }}$

\begin{tabular}{lcc}
\hline Variable shocked, $\mathbf{1 9 9 0}$ to $\mathbf{2 0 0 8}$ & Shock, \% change \\
\hline Population: $^{\mathrm{b}}$ & Low income household & 15.3 \\
& Professional household & 5.4 \\
Total factor productivity $^{\mathrm{c}}$ & 18.1 \\
Factor shares: $^{\mathrm{d}}$ & Low-skill labour & -30.8 \\
& Skill & 0.0 \\
& Capital & 13.7 \\
Depreciation rate $^{\mathrm{e}}$ & 50.0 \\
\hline
\end{tabular}

a These shocks are chosen as "central" to the prospective analysis. Unlike the retrospective analysis, there are no shocks to the relative price of capital goods, which is anticipated to be affected by a slowing of Moore's Law and the consolidation of the global IT sector into oligopolies, fiscal balance and participation rates. Anticipation of the latter two would be arbitrary and beyond the scope of this analysis.

b These population shocks are consistent with UN-projected growth of the US population to 366 million by 2036, with 10\% of increment in the professional category.

c The central total factor productivity increment assumes a continuation of the average growth rate of productivity between 1990 and 2016, according to the Penn World Tables (Feenstra et al. 2015).

d The projected changes in shares are as per Figure 6.

e The depreciation rate is shocked upward in the prospective analysis because of the expectation that, as the proportion of the capital stock comprising IT equipment rises, rates of obsolescence will also rise. For this purpose the links between the overall depreciation rate (the ratio of capital consumption to the capital stock, from FRED), the rate of TFP growth and the low-skill labour share are explored econometrically. The results endorse a rise from $4 \%$ to $6 \%$ over two decades. 
Table 8: Prospective Changes with Automation in the US - “Central” Projection, 2016-2036

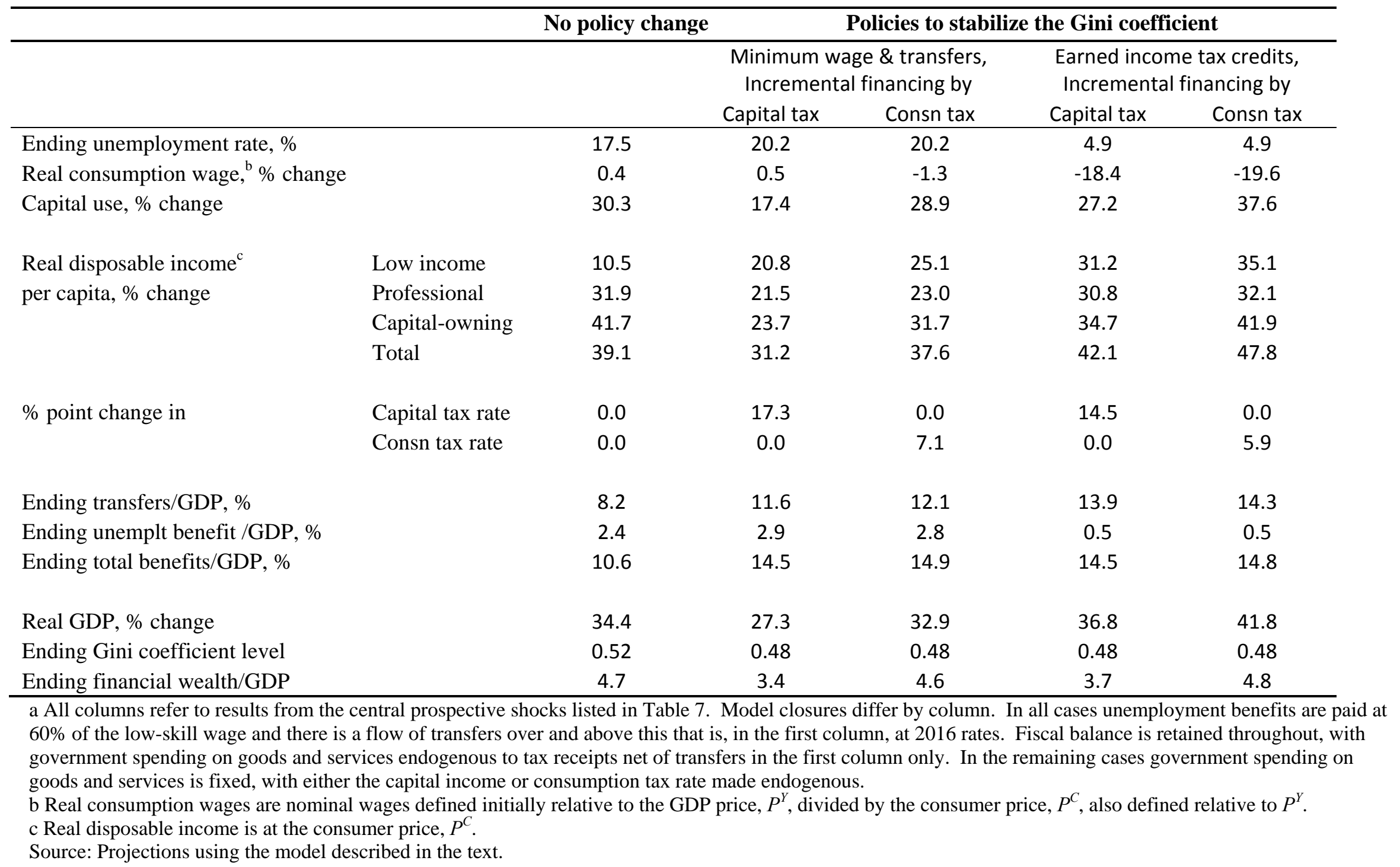




\section{Appendix: Model Parameters and Operation}

Table A1: Key Parameters, Representing the US in 2016

\begin{tabular}{|c|c|}
\hline & US \\
\hline Depreciation rate $^{a}$ & 0.04 \\
\hline \multicolumn{2}{|l|}{ Production factor shares ${ }^{b}$} \\
\hline Labour, $\beta^{L}$ & 0.180 \\
\hline Skill, $\beta^{S}$ & 0.415 \\
\hline Capital, $\beta^{K}$ & 0.405 \\
\hline \multicolumn{2}{|c|}{ Initial household consumption volume shares ${ }^{\mathrm{c}}$} \\
\hline Low income & 0.35 \\
\hline Professional & 0.33 \\
\hline Capital owning & 0.32 \\
\hline \multicolumn{2}{|l|}{ Initial household saving rates ${ }^{\mathrm{d}},{ }^{\mathrm{c}}$} \\
\hline Low income & -2.5 \\
\hline Professional & 22.7 \\
\hline Capital owning & 34.5 \\
\hline \multicolumn{2}{|l|}{ Income tax rates (revealed) on ${ }^{\mathrm{e}}$} \\
\hline Labour income, $t^{L}$ & 0.150 \\
\hline Professional income, $t^{S}$ & 0.250 \\
\hline Capital income, $t^{K}$ & 0.050 \\
\hline Indirect (consumption) tax rate, $t^{C}$ & 0.140 \\
\hline Unemployment benefit ratio, $\alpha$ & 0.60 \\
\hline \multicolumn{2}{|l|}{ Transfer rates / GDP, $t_{h}^{R}=T_{h}^{R} / Y, \%$} \\
\hline Low income & 5.6 \\
\hline Prof income & 1.6 \\
\hline Capital owning & 0.0 \\
\hline \multicolumn{2}{|l|}{ Elasticities $^{\mathrm{f}}$} \\
\hline \multicolumn{2}{|l|}{ Consumption, $c$ to $r, \varepsilon^{C R}$} \\
\hline Low income & 0.02 \\
\hline Prof income & 0.10 \\
\hline Capital owning & 0.20 \\
\hline \multicolumn{2}{|l|}{ Consumption, $c$ to $Y^{D}, \varepsilon^{C Y}$} \\
\hline Low income & 1.05 \\
\hline Prof income & 0.98 \\
\hline Capital owning & 0.90 \\
\hline Investment, $I_{i}$ to $r_{i}^{C} / r_{i}, \varepsilon_{i}^{I}$ & 1.00 \\
\hline Premium to $G / T, \phi_{i}$ & 0.20 \\
\hline
\end{tabular}

a The depreciation rate is the ratio of capital consumption to the capital stock, from FRED.

b Value added shares are based.

c Initial consumption value shares are used to calibrate consumption structure of the model database.

$\mathrm{d}$ Initial household saving rates are from disposable income. These emerge from the calibration and are indicative of embodied behaviour but do not remain constant in response to shocks.

e These income tax rates are "revealed" in the sense that they are derived from the collections reported by the Congressional Budget Office and the tax bases implied by the model database.

f Consumption elasticities are consistent with a variety of estimates in use in other models, both of marginal propensities and elasticities (including McKibbin and Wilcoxen 1995 and Jin 2011). 
Table A2: Closures: Choices of Exogenous Variables ${ }^{a}$

Long run equilibrium analysis

Labour market

Back-casting to 1990

Endogenous: low-skill wage, $W$

Exogenous: employment of low-skill workers, $L$

Prospective shocks:

Exogenous: nominal production wage, $W$

Endogenous: Employment of low-skill workers, $L$

Fiscal policy

Back-casting to 1990

Exogenous net government saving after transfers, $S^{G}$

Tax and transfer rates exogenous and shocked

Government expenditure endogenous to retain $S^{G}$

Prospective shocks

Exogenous: net government saving after transfers, $S^{G}$

Exogenous government expenditure on goods, $G$

Exogenous welfare of low-skill household members

Endogenous: power of either consumption tax rate, $\tau_{C}$ or capital income tax rate, $\tau_{K}$.

a Closures vary in the prospective analysis, as noted in the discussion of results. 
Editor, UWA Economics Discussion Papers:

Sam Hak Kan Tang

University of Western Australia

35 Sterling Hwy

Crawley WA 6009

Australia

Email: ecoadmin@biz.uwa.edu.au

The Economics Discussion Papers are available at:

1980 - 2002: $\quad$ http://ecompapers.biz.uwa.edu.au/paper/PDF\%20of\%20Discussion\%20Papers/

Since 2001: $\quad$ http://ideas.repec.org/s/uwa/wpaper1.html

Since 2004: $\quad$ http://www.business.uwa.edu.au/school/disciplines/economics

\begin{tabular}{|c|c|c|}
\hline \multicolumn{3}{|c|}{ ECONOMICS DISCUSSION PAPERS - 2016} \\
\hline $\begin{array}{l}\text { DP } \\
\text { NUMBER }\end{array}$ & AUTHORS & TITLE \\
\hline 16.01 & Xu, R., Wu, Y. and Luan, J. & $\begin{array}{l}\text { ANALYSIS OF FARMERS’ WILLINGNESS TO ADOPT } \\
\text { GENETICALLY MODIFIED INSECT-RESISTANT RICE IN } \\
\text { CHINA }\end{array}$ \\
\hline 16.02 & $\begin{array}{l}\text { Lia, Y., Fan, J., Zhao, D., Wu, Y. and } \\
\text { Li, J. }\end{array}$ & $\begin{array}{l}\text { TIERED GASOLINE PRICING: A PERSONAL CARBON } \\
\text { TRADING PERSPECTIVE }\end{array}$ \\
\hline 16.03 & Clements, K.W., Lan, Y. and Si, J. & UNCERTAINTY IN CURRENCY MISPRICING \\
\hline 16.04 & Parsons, C. and Vézina, P.L. & $\begin{array}{l}\text { MIGRANT NETWORKS AND TRADE:THE VIETNAMESE } \\
\text { BOAT PEOPLE AS A NATURAL EXPERIMENT }\end{array}$ \\
\hline 16.05 & Chang, S., Connelly, R. and Ma, P. & $\begin{array}{l}\text { WHAT WILL YOU DO IF I SAY 'I DO’?: THE EFFECT OF } \\
\text { THE SEX RATIO ON TIME USE WITHIN TAIWANESE } \\
\text { MARRIED COUPLES }\end{array}$ \\
\hline 16.06 & Yu, F. and Wu, Y. & $\begin{array}{l}\text { BIASES IN PATENT EXAMINATION AND FIRMS’ } \\
\text { RESPONSES: EVIDENCE FROM THE } \\
\text { PHARMACEUTICAL INDUSTRY }\end{array}$ \\
\hline 16.07 & $\begin{array}{l}\text { Fan, J., Li, J., Wu, Y., Wang, S. and } \\
\text { Zhao, D. }\end{array}$ & $\begin{array}{l}\text { THE EFFECTS OF ALLOWANCE PRICE ON ENERGY } \\
\text { DEMAND UNDER A PERSONAL CARBON TRADING } \\
\text { SCHEME }\end{array}$ \\
\hline 16.08 & Golley, J., Tyers, R. and Zhou, Y. & $\begin{array}{l}\text { CONTRACTIONS IN CHINESE FERTILITY AND } \\
\text { SAVINGS: LONG RUN DOMESTIC AND GLOBAL } \\
\text { IMPLICATIONS }\end{array}$ \\
\hline 16.09 & McGrath, G. and Neill, K. & $\begin{array}{l}\text { FOREIGN AND DOMESTIC OWNERSHIP IN WESTERN } \\
\text { AUSTRALIA'S GAS MARKET }\end{array}$ \\
\hline 16.10 & Clements, K.W. and Si, J. & SIMPLIFYING THE BIG MAC INDEX \\
\hline 16.11 & Priyati, R.Y. and Tyers, R. & $\begin{array}{l}\text { PRICE RELATIONSHIPS IN VEGETABLE OIL AND } \\
\text { ENERGY MARKETS }\end{array}$ \\
\hline 16.12 & Wu, J., Wu, Y. and Wang, B. & $\begin{array}{l}\text { THE GREENNESS OF CHINESE CITIES: CARBON } \\
\text { DIOXIDE EMISSION AND ITS DETERMINANTS }\end{array}$ \\
\hline 16.13 & $\begin{array}{l}\text { Arslan, C., Dumont, J.C., Kone, Z., } \\
\text { Özden, Ç., Parsons, C. and } \\
\text { Xenogiani, T. }\end{array}$ & $\begin{array}{l}\text { INTERNATIONAL MIGRATION TO THE OECD IN THE } \\
\text { TWENTY-FIRST CENTURY }\end{array}$ \\
\hline 16.14 & Tomioka, K. and Tyers, R. & $\begin{array}{l}\text { HAS FOREIGN GROWTH CONTRIBUTED TO } \\
\text { STAGNATION AND INEQUALITY IN JAPAN? }\end{array}$ \\
\hline
\end{tabular}




\begin{tabular}{|c|c|c|}
\hline 16.15 & Donovan, J. and Hartley, P. & $\begin{array}{l}\text { RIDING THE IRON ORE CYCLE: ACTIONS OF } \\
\text { AUSTRALIA'S MAJOR PRODUCERS }\end{array}$ \\
\hline 16.16 & Czaika, M. and Parsons, C. & $\begin{array}{l}\text { HIGH-SKILLED MIGRATION IN TIMES OF GLOBAL } \\
\text { ECONOMIC CRISIS }\end{array}$ \\
\hline 16.17 & Lefroy, T., Key, J. and Kingwell, R. & $\begin{array}{l}\text { A LONGITUDINAL EXAMINATION OF BROADACRE } \\
\text { FARM SIZE AND PERFORMANCE IN WESTERN } \\
\text { AUSTRALIA }\end{array}$ \\
\hline 16.18 & Arthmar, R. and McLure, M. & $\begin{array}{l}\text { SRAFFA, MYRDAL AND THE } 1961 \text { SÖDERSTRÖM GOLD } \\
\text { MEDAL }\end{array}$ \\
\hline 19.19 & Azwar, P. and Tyers, R. & $\begin{array}{l}\text { POST-GFC EXTERNAL SHOCKS AND INDONESIAN } \\
\text { ECONOMIC PERFORMANCE }\end{array}$ \\
\hline 19.20 & Chen, A. and Groenewold, N. & $\begin{array}{l}\text { OUTPUT SHOCKS IN CHINA: DO THE DISTRIBUTIONAL } \\
\text { EFFECTS DEPEND ON THE REGIONAL SOURCE? }\end{array}$ \\
\hline 19.21 & Wu, Y., Zhu, X. and Groenewold, N. & $\begin{array}{l}\text { THE DETERMINANTS AND EFFECTIVENESS OF } \\
\text { INDUSTRIAL POLICY IN CHINA: A STUDY BASED ON } \\
\text { FIVE-YEAR PLANS }\end{array}$ \\
\hline 16.22 & Liu, H. & $\begin{array}{l}\text { THE INCOME AND PRICE SENSITIVITY OF DIETS } \\
\text { GLOBALLY }\end{array}$ \\
\hline 16.23 & Asano, A., Neill, K. and Yamazaki, S. & $\begin{array}{l}\text { DECOMPOSING FISHING EFFORT: MODELLING THE } \\
\text { SOURCES OF INEFFICIENCY IN A LIMITED-ENTRY } \\
\text { FISHERY }\end{array}$ \\
\hline 16.24 & Golley, J., Tyers, R. and Zhou, Y. & $\begin{array}{l}\text { FERTILITY AND SAVINGS CONTRACTIONS IN CHINA: } \\
\text { LONG-RUN GLOBAL IMPLICATIONS }\end{array}$ \\
\hline 16.25 & Taylor, G., Tyers, R. & $\begin{array}{l}\text { SECULAR STAGNATION: DETERMINANTS AND } \\
\text { CONSEQUENCES FOR AUSTRALIA }\end{array}$ \\
\hline
\end{tabular}

\begin{tabular}{|c|c|c|}
\hline \multicolumn{3}{|c|}{ ECONOMICS DISCUSSION PAPERS - 2017} \\
\hline $\begin{array}{l}\text { DP } \\
\text { NUMBER }\end{array}$ & AUTHORS & TITLE \\
\hline 17.01 & Tyers, R. and Zhou, Y. & $\begin{array}{l}\text { AUTOMATION AND INEQUALITY WITH TAXES AND } \\
\text { TRANSFERS }\end{array}$ \\
\hline 17.02 & Ye, L. and Robertson, P. & $\begin{array}{l}\text { HITTING THE GREAT WALL: RURAL-URBAN } \\
\text { MIGRATION AND CHINA'S GROWTH SLOWDOWN }\end{array}$ \\
\hline 17.03 & Ye, L. and Robertson, P. & $\begin{array}{l}\text { MIGRATION AND GROWTH IN CHINA: A SCEPTICAL } \\
\text { ASSESSMENT OF THE EVIDENCE }\end{array}$ \\
\hline 17.04 & Clements, K. Si, J. and Vo, L. & $\begin{array}{l}\text { FOOD AND AGRICULTURAL PRICES ACROSS } \\
\text { COUNTRIES AND THE LAW OF ONE PRICE }\end{array}$ \\
\hline 17.05 & $\begin{array}{l}\text { Chen, M., Clements, K., Gao, G. and } \\
\text { Si, J. }\end{array}$ & THREE FACTS ABOUT WORLD METAL PRICES \\
\hline 17.06 & $\begin{array}{l}\text { Cornes, R., Fiorini, L. and } \\
\text { Maldonado, W. }\end{array}$ & $\begin{array}{l}\text { EXPECTATIONAL STABILITY IN AGGREGATIVE } \\
\text { GAMES }\end{array}$ \\
\hline 17.07 & Hartley, P. & $\begin{array}{l}\text { THE COST OF DISPLACING FOSSIL FUELS: SOME } \\
\text { EVIDENCE FROM TEXAS }\end{array}$ \\
\hline 17.08 & Shehabi, M. R. & ASSESSING KUWAITI ENERGY PRICINING REFORMS \\
\hline 17.09 & Perdana, S. and Tyers, R. & $\begin{array}{l}\text { GLOBAL CLIMATE CHANGE MITIGATION: STRATEGIC } \\
\text { INTERACTION OR UNILATERAL GAINS? }\end{array}$ \\
\hline 17.10 & McLure, M. & $\begin{array}{l}\text { RICARDIAN EQUIVALENCE, THE ITALIAN FISCAL } \\
\text { TRADITION AND WA GOVERNMENT NET DEBT }\end{array}$ \\
\hline 17.11 & Trinh, J. & $\begin{array}{l}\text { THE PARETO DISTRIBUTION AND ITS RELATIONSHIP } \\
\text { TO PIKETTY'S THIRD FUNDAMENTAL LAW OF } \\
\text { CAPITALISM }\end{array}$ \\
\hline
\end{tabular}




\begin{tabular}{|c|c|c|}
\hline 17.12 & McLure, M. & $\begin{array}{l}\text { THINKING OUTSIDE THE BOX: A NEW HISTORY OF } \\
\text { EDGEWORTH'S AND PARENTO'S DEVELOPMENT OF } \\
\text { THE BOX DIAGRAM }\end{array}$ \\
\hline 17.13 & Zhou, Y. and Tyers, R. & AUTOMATION AND INEQUALITY IN CHINA \\
\hline 17.14 & Arthmar, R. and McLure, M. & $\begin{array}{l}\text { THE ECONOMIC AND SOCIAL CONSEQUENCES OF THE } \\
\text { WAR: PIGOU, THE PRESS AND THE STRUGGLE FOR AN } \\
\text { HONOURABLE PEACE }\end{array}$ \\
\hline 17.15 & Shehabi, M. R. & $\begin{array}{l}\text { CONTEMPORARY KUWAITISATION DYNAMICS AND } \\
\text { THEIR HISTORICAL PERSPECTIVES }\end{array}$ \\
\hline 17.16 & Clements, K. and Si, J. & $\begin{array}{l}\text { WHAT DO AUSTRALIAN ECONOMICS PhDs DO? THE } \\
\text { UWA EXPERIENCE }\end{array}$ \\
\hline 17.17 & Arthmar, R. and McLure, M. & KEYNES AND THE ROYAL SWEDISH ACADEMY \\
\hline
\end{tabular}

